\title{
The Congressional Debate on Partial-Birth Abortion: Constitutional Gravitas and Moral Passion
}

\author{
CHERYL SCHONHARDT-BAILEY*
}

\begin{abstract}
Automated content analysis is employed to measure the dimensionality of Senate debates on the 2003 Partial-Birth Abortion Ban Act and compare these results with the final vote. The underlying verbal conflict leading up to the final roll-call vote contains two important dimensions: (1) an emotive battle over the abortion procedure itself, and (2) the battle over the constitutionality of the bill. Surprisingly, senators appear not to have voted along the first dimension of the verbal conflict, but rather along the second dimension. The analysis of the deliberations of senators not only enables us to understand the complexity of the arguments that is not captured in the vote, but it also uncovers (and measures empirically) the strategies employed by legislators to shape the relevant lines of conflict, and ultimately, the final content of the bill.
\end{abstract}

On 18 April 2007 the Supreme Court upheld, by a majority of five to four, a 2003 federal ban on a specific method of late-term abortion known medically as D \& X (dilation and extraction), and to others as 'partial-birth abortion'. In Gonzales v. Carhart, it overruled six federal courts and appeared to reverse its own ruling in 2000, in which it voted five-to-four to strike down a similar state law. The 2007 decision thus signals a shift in the Court's stance on abortion, namely that although the availability of legalized abortion is upheld (as established in 1973 with Roe v. Wade), restrictions should be imposed on the method of abortion. Moreover, this is the first time that the Court has upheld an abortion ban which contains no exception to preserve a woman's health.

Any number of factors may have shaped the Court opinion. ${ }^{1}$ However, one overriding feature of the 2007 decision distinguishes it from the 2000 ruling - Congress deliberately crafted the 2003 ban to withstand critical scrutiny by the Supreme Court. To this end, in crafting the federal ban and manœuvring it to the final roll-call vote in October 2003,

\footnotetext{
* Department of Government, London School of Economics and Political Science. An earlier version of this article was presented at the Conference on Comparative Analysis of Legislative Behavior, University of California, San Diego, 2006. The author is grateful to participants at that conference for their comments and also particularly grateful to Andrew Bailey, Bernie Grofman, David Mayhew, Albert Weale, an anonymous reviewer, and her own students at LSE for their comments and suggestions. She is also indebted to Gordon Bannerman for assistance in preparing the text for analysis and to Mina Moshkeri for assistance in producing the final graphics.

1 A number of reasons may be given for the apparent shift in opinion: (1) George Bush's two conservative appointees, John Roberts and Samuel Alito ('Justices Back Ban on Method of Abortion', New York Times, 19 April 2007 (< nytimes.com/2007/04/19/Washington/19scotus.html > )); (2) the apparent replacement of Sandra Day O'Connor with either Anthony Kennedy or Samuel Alito as the swing vote ('The Supreme Court: Conservatives resurgent', The Economist, 21 April 2007, p. 54; Joannan Grossman and Linda McClain, 'New Justices, New Rules: The Supreme Court Upholds the Federal Partial-Birth Abortion Ban Act of 2003', Findlaw: Legal News and Commentary (1 May 2007), < http://writ.news.findlaw.com/commentary/ 20070501_mcclain.html >); (3) the Court following the opinion of an American public which favours some restrictions on abortion (Morris P. Fiorina, Samuel J. Abrams and Jeremy C. Pope, Culture War? The Myth of a Polarized America (New York: Pearson Longman, 2005), pp. 42-4; John Yoo, 'Partial-birth bigotry', Wall Street Journal, 28 April 2007, republished by the American Enterprise Institute, 30 April 2007 ( $<$ aei.org >)); and (4) the emergence of a Catholic majority among Supreme Court justices ('The Supreme Court's Catholic majority', New York Times, 25 April 2007 ( < nytimes.com/2007/04/25/us/politics >); 'Subtext of abortion ruling: Religion', International Herald Tribune, 26 April 2007, p. 4; Yoo, 'Partial-birth bigotry').
} 
Republican members of Congress (MCs) employed a number of tactics: they included congressional fact findings to strengthen the constitutional case; they deflected both floor amendments and scrutiny by the judiciary committee; and they framed the procedure itself as the equivalent of infanticide.

While the final roll-call vote in the Senate is important in its own right, an analysis of the vote reveals only a simplification of the preferences of MCs. By looking only at the vote, we cannot determine the reasons why members of Congress cast their votes as they did. There is, therefore, a strong case for moving beyond the analysis of the roll-call vote to examine the arguments, deliberations and rhetoric that shaped the content of the bill and the outcome.

This article explores the means by which senators evaluated and debated the Partial-Birth Abortion (PBA) Ban Act of $2003,{ }^{2}$ and thus the framing or spin used by some of the legislators to shape the content and passage of the bill. ${ }^{3}$ This brings together the multidimensionality of deliberation and Keith Poole's finding of single-dimensionality ${ }^{4}$ in the final roll-call vote. ${ }^{5}$ A relatively new methodology is used here for analysing dimensionality in a legislative setting. I employ automated content software (ALCESTE) to analyse Senate debates on the PBA Ban and compare these results with Poole's depiction of the final roll-call vote on this legislation in October 2003. While the final vote on this bill appears to be, as Poole argues, one dimensional, the underlying conflict leading up to the final vote contains two important dimensions: the first is an emotive and personal battle over the particular abortion procedure which the bill sought to ban; and the second is a legal/constitutional battle over the constitutionality of the bill.

2 'Partial-birth Abortion Ban Act of 2003', 18 USC, 1531, Public Law 108-105.

3 In a similar vein, Scott L. Feld, Bernard Grofman and Joseph Godfrey, 'Putting a Spin on It: Geometric Insights into How Candidates with Seemingly Losing Positions Can Still Win' (unpublished manuscript, 2006) argue that politicians may use 'spin' (or the reframing of issues by use of persuasion) to simplify multiple issue dimensions into a single new dimension, and thereby improve their competitive edge among voters.

${ }^{4}$ Keith T. Poole, Spatial Models of Parliamentary Voting (Cambridge: Cambridge University Press, 2005).

5 A number of recent studies of legislative and other political behaviour have sought to explore the links between multidimensionality and low-dimensionality. Some of these explore the question by analysing roll-call votes (Tim Groseclose, Steven D. Levitt and James M. Snyder Jr, 'Comparing Interest Group Scores Across Time and Chambers: Adjusted ADA Scores for the U.S. Congress', American Political Science Review, 93 (1990), 33-50; Noelle H. Norton, 'Uncovering the Dimensionality of Gender Voting in Congress', Legislative Studies Quarterly, 24 (1999), 65-86; Mark S. Hurwitz, Roger J. Moiles and David W. Rohde, 'Distributive and Partisan Issues in Agriculture Policy in the 104th House', American Political Science Review, 95 (2001), 911-22); others by analysing survey or elite interview data with correlational and confirmatory factor analysis (Stephen C. Craig, Michael D. Martinez and James G. Kane, 'The Structure of Political Competition: Dimensions of Candidate and Group Evaluation Revisited', Political Behavior, 21 (1999), 283-304; Jeffrey Levine, Edward G. Carmines and Paul M. Sniderman, 'The Empirical Dimensionality of Racial Stereotypes', Public Opinion Quarterly, 63 (1999), 371-84) or principal-component analysis (Torsten J. Selck, 'On the Dimensionality of European Union Legislative Decision-making', Journal of Theoretical Politics, 16 (2004), 203-22); and others by comparing and contrasting alternative methodological approaches (Timothy J. Brazill and Bernard Grofman, 'Factor Analysis versus Multidimensional Scaling: Binary Choice Roll-Call Voting and the U.S. Supreme Court', Social Networks, 24 (2002), 201-29; Bernard Grofman and Timothy J. Brazill, 'Identifying the Median Justice on the Supreme Court Through Multidimensional Scaling: Analysis of "Natural Courts" 1953-1991', Public Choice, 112 (2002), 55-79). Two further studies offer insights on multi- and low-dimensionality by examining the legislative process, both before and after floor voting (Matthew Potoski and Jeffery Talbert, 'The Dimensional Structure of Policy Outputs: Distributive Policy and Roll Call Voting', Political Research Quarterly, 53 (2000), 695-710; Nils Ringe, 'Policy Preference Formation in Legislative Politics: Structures, Actors, and Focal Points', American Journal of Political Science, 49 (2005), 731-45). 
Intuitively, one might expect the final vote to divide along the first dimension, inasmuch as it received relatively more attention in the debates, but this is not the case. Surprisingly, senators appear to have divided along the second dimension - i.e., the issue of constitutionality. Hence, while Poole's roll-call analysis portrays the vote as mainly the product of general attitudes on the liberal-conservative scale (and implicitly assumes that the legislative process serves to transform these attitudes into a choice), textual analysis of the debates reveals the importance of constitutionality to the rhetoric of support or opposition. MCs legitimized their votes with reference to their contrasting interpretations of the meaning of the constitution with respect to abortion rights, namely whether or not a woman's access to a particular method of abortion could be contingent upon her health (as firmly established in Roe v. Wade). While these contrasting interpretations may be subsumed within a liberal-conservative attitudinal dimension, this is not to say that they are synonymous with it. Instead, because the constitutional dimension appears to emerge as a product of the process of deliberation, this process itself should not simply be interpreted as a means to transform liberal-conservative attitudes into a roll-call vote. Rather, the process of deliberation introduces a substantive dimension of its own - namely, the constitutional dimension. ${ }^{6}$

Members of Congress may pursue a number of goals in their floor votes - good public policy, partisan and/or ideological goals, and satisfying constituents in order to gain re-election. ${ }^{7}$ In the PBA Ban, the primary strategy of the ban's supporters was to enact a law that - assuming (with almost perfect certainty) that opponents would launch a constitutional challenge ${ }^{8}-$ the Supreme Court would uphold. As a longer-term strategy, this outcome would constitute one step in a gradual 'squeeze' on abortion rights. In the Senate roll-call vote, MCs were certainly motivated by their own ideological stance on abortion (and in this sense, their positions on a liberal-conservative scale shaped their votes); but they also sought to claim credit from their constituents for the final policy outcome - an outcome which invariably would require the judgment of the Supreme Court. As Martin has argued, MCs are constrained by the separation of powers and thus to pursue re-election and other goals, they are not as concerned with particular roll-call votes as they are with the ultimate policy outcome. ${ }^{9}$ With the 2003 PBA Ban Act, senators acted upon their oath to defend the constitution by clashing with each other to define the meaning of

${ }^{6}$ My thanks to Albert Weale for helping to clarify this point.

7 John W. Kingdon, Congressmen's Voting Decisions, 3rd edn (Ann Arbor: University of Michigan Press, 1989); David R. Mayhew, Congress: The Electoral Connection (New Haven, Conn.: Yale University Press, 1974); Richard Fenno, Congressmen in Committtees (Boston, Mass.: Little, Brown, 1973); Eric M. Uslaner, The Movers and the Shirkers: Representatives and Ideologues in the Senate (Ann Arbor: University of Michigan Press, 1999); Keith T. Poole and Howard Rosenthal, Congress: A Political-Economic History of Roll-Call Voting (Oxford: Oxford University Press, 1997).

${ }^{8}$ Less than one hour after the ban became law, Richard Kopf, Chief Judge of the US District Court for Nebraska, issued a limited temporary restraining order against the ban, arguing that it lacked an exception if the woman's health is at risk. The Act was subsequently ruled unconstitutional in other federal district courts. In 2004, the four doctors who had challenged the Nebraska state law in Stenberg v. Carhart disputed the congressional findings, arguing that the procedure is safe under some conditions and could avoid complications to the woman. In Carhart v. Ashcroft (2004), Judge Kopf ruled that the four doctors had demonstrated that the congressional findings were 'unreasonable' and that the Act was unconstitutional on the grounds that it failed to provide a health exception for women. In 2005, the 8th Circuit Court in St Louis upheld the decision of Kopf in Carhart v. Ashcroft, whereupon the Bush Administration appealed (Gonzales v. Carhart, No. 05-380). In 2006, the Supreme Court agreed to hear the appeal.

9 Andrew D. Martin, 'Congressional Decision Making and the Separation of Powers', American Political Science Review, 95 (2001), 361-78. 
the constitution. The idea of Congress acting to supplement the Supreme Court in considering constitutional issues is well established; ${ }^{10}$ however, the case of the federal ban of 2003 provides an excellent example of this idea put into practice.

In sum, the analysis of this article not only enables us to understand the complexity of the arguments that is not captured in the vote, but it also uncovers (and measures empirically) the strategies employed by legislators to shape the relevant lines of conflict, and in so doing, complements recent studies of deliberation of congressional debates. ${ }^{11}$ The next section describes the case of the Partial-Birth Abortion Ban Act; a discussion of the data follows with a brief description of the methodology (while a fuller description is given in Appendix 1); the next section gives the results of the analysis; and there is a final discussion of the results in the light of what they reveal about the importance of the legislative process for the final outcome

THE CASE OF THE PARTIAL-BIRTH ABORTION BAN ACT

\section{Background}

Party polarization on abortion. Abortion is one of the most prominent issues in recent times to have sparked the passions of Americans. ${ }^{12}$ Adams has argued persuasively that abortion is one of the key issues driving ideological polarization between the Democratic and Republican party elites. ${ }^{13}$ Paralleling the findings of Poole and Rosenthal, ${ }^{14}$ he identifies a clear partisan trend on abortion in Congressional roll-call votes from 1979 onwards, with Democrats becoming increasingly 'pro-choice' and Republicans increasingly 'pro-life'. ${ }^{15}$ This has resulted in more internal party cohesion on the abortion issue and clearer party signals to the electorate. ${ }^{16}$

10 Donald G. Morgan, Congress and the Constitution: A Study of Responsibility (Cambridge, Mass.: Belknap Press of Harvard University Press, 1966); Keith E. Whittington, Constitutional Construction: Divided Powers and Constitutional Meaning (Cambridge, Mass.: Harvard University Press, 1999).

11 Paul J. Quirk, 'Deliberation and Decision Making', in Paul J. Quirk and Sarah A. Binder, eds, The Legislative Branch (Oxford: Oxford University Press, 2005), pp. 314-48; and Gary Mucciaroni and Paul J. Quirk, Deliberative Choices: Debating Public Policy in Congress (Chicago: University of Chicago Press, 2006).

${ }^{12}$ One need look no further than contemporary media coverage to sustain this assessment. However, a number of recent books on abortion politics and abortion discourse in the United States have sought to explain the underlying conflicts between the pro-life and pro-choice camps, including: Myra Marx Ferree, William Anthony Gamson, Jürgen Gerhards and Dieter Rucht, Shaping Abortion Discourse: Democracy and the Public Sphere in Germany and the United States (Cambridge: Cambridge University Press, 2002); Carol J. Maxwell, Pro-Life Activists in America: Meaning, Motivation and Direct Action (Cambridge: Cambridge University Press, 2002); William Saletan, Bearing Right: How Conservatives Won the Abortion War (Berkeley: University of California Press, 2004); Gene Burns, The Moral Veto: Framing Contraception, Abortion, and Cultural Pluralism in the United States (Cambridge: Cambridge University Press, 2005).

${ }^{13}$ Greg D. Adams, 'Abortion: Evidence of an Issue Evolution', American Journal of Political Science, 41 (1997), 718-37.

14 Poole and Rosenthal, pp. 112-13.

15 The terms 'pro-choice' and 'pro-life' are clearly value-laden and may thus be considered objectionable. Yet inasmuch as these terms are commonly used in both popular and academic works, and they embody the frames used by both camps of the abortion debate, they are used here - although their problematic nature is acknowledged.

${ }^{16}$ Carmines and Wood refine the issue evolution thesis by confirming that activists in both parties have followed this pattern, with Democratic activists moving towards pro-choice and Republican activists towards pro-life (Edward G. Carmines and James Woods, 'The Role of Party Activists in the Evolution of the Abortion Issue', Political Behavior, 24 (2002), 361-77). These authors find, moreover, that from the 1990s onwards, abortion attitudes in the electorate have followed the polarization pattern set by political elites. These authors and Adams 
The procedure. In a National Abortion Federation Risk Management Seminar paper in 1992, Dr Martin Haskell detailed a procedure for second trimester abortion, which he termed 'Dilation and Extraction' (or D \& X) to distinguish it from the classic D \& E (dilation and evacuation) procedure, in which the fetus is dismembered inside the uterus before removal. ${ }^{17} \mathrm{In}$ the $\mathrm{D} \& \mathrm{X}$ procedure, the doctor dilates the cervix and then removes the fetus feet-first. With all but the head of the fetus delivered, the doctor uses a pair of Metzenbaum scissors to puncture the base of the skull and then inserts a suction catheter into the hole to evacuate the contents of the skull, after which the fetus is completely removed from the patient. ${ }^{18}$

Partial-birth abortion bans. This procedure came to be described by many pro-life proponents as 'partial-birth abortion' (PBA), in part because the term essentially recasts abortion as infanticide. For pro-lifers: 'The baby was emerging into the world, only to be stopped, stabbed, and crushed. This was no mere abortion. It was a brutally thwarted "birth" '. ${ }^{19}$ Saletan further argues that Republicans latched onto this abortion method as a way to 'move the abortion debate out of the woman's body' and thereby render moot the notion of a woman's choice and control over her body. ${ }^{20}$

Pro-choice proponents vehemently oppose this labelling of the procedure, arguing that it is not a medical term and that the so-called birth is artificial and premature. They further maintain that physicians should decide the abortion procedure most appropriate to the needs of the woman, and in cases of late-term abortion, this may be D \& E or D \& X. ${ }^{21}$ At issue is whether the method of abortion (at whatever stage in the pregnancy) ought to be left to the discretion of physicians or whether legislators should have a say in which methods are acceptable and which are not. Or, as one critic of the 2003 Act succinctly states: 'if a mother has a right to choose abortion in the first place, she has a right to choose the safest method regardless of whether the fetus is terminated inside or outside the uterus.' $^{22}$

(F'note continued)

identify a trend towards party polarization on abortion beginning in Congress and subsequently spreading to the electorate. Fiorina et al., by contrast, take issue with the broader notion of a polarized political culture in the United States. On abortion, Americans are said to be 'pro-choice, buts' - that is, in favour of abortion with some restrictions (Morris P. Fiorina, et al., Culture War? pp. 42-4). With respect to party polarization on abortion, these authors readily accept a clear divide between pro-choice Democrats and pro-life Republicans who are party activists, political office-holders and lobbyists groups. Contrary to Carmines and Woods, they argue that rank-and-file Democrats and Republicans have not absorbed the signals from activists and politicians on abortion. So, while all these authors accept a trend in party polarization on abortion among political elites and activists, researchers continue to debate the extent to which the mass public has followed this clear trend (for example, Thomas M. Carsey and Geoffrey C. Layman, 'Changing Sides or Changing Minds? Party Identification and Policy Preferences in the American Electorate', American Journal of Political Science, 50 (2006), 464-77) and whether rank-and-file Democrats and Republicans have listened to the partisan message from the elites and activists.

${ }^{17}$ Martin Haskell, 'Dilation and Extraction for Late Second Trimester Abortion' (National Abortion Federation Risk Management Seminar, Dallas, Texas, 1992).

${ }^{18}$ Haskell, 'Dilation and Extraction for Late Second Trimester Abortion', pp. 30-1.

19 Saletan, Bearing Right, p. 233.

${ }^{20}$ Saletan, Bearing Right, p. 233.

${ }^{21}$ PP - Planned Parenthood Federation, 'Abortion after the First Trimester: Legality of Abortion (Laws and Specific Abortion Techniques)', < http://www.plannedparenthood.org/pp2/portal/> accessed 18 March 2006.

${ }^{22}$ Jason Abaluck, 'Partial truths: The partial-birth abortion ban violates women's rights', Perspective, Harvard-Radcliffe's Liberal Monthly (November 2003), < http://www.digitas.harvard.edu/ perspy/issues/ 2003/nov/partial.html > , accessed 24 March 2006. 
The first attempt by Congress to ban the procedure was the Partial-Birth Abortion Ban Act of 1995. The House overrode President Clinton's 1996 veto of the bill, but the Senate was several votes short with a margin of fifty-eight yeas to forty nays. ${ }^{23}$ Again, in 1997, Congress passed a ban on partial-birth abortion and again it was vetoed by President Clinton. The House overrode the veto with even more votes than in 1996, but the override narrowly failed in the Senate by 64 to 36. Subsequently, a number of states passed bans on the procedure, giving rise to numerous court cases against the state bans on the grounds that the bans were unconstitutional. One such case, Stenberg v. Carhart (2000) reached the Supreme Court, and in a five to four decision the Court struck down a Nebraska law that made partial-birth abortion illegal because it failed to create an exception for the woman's health and because the statute was deemed ambiguous (i.e., it might be construed as banning some D \& E procedures). Inasmuch as the Supreme Court required exceptions for the health of the mother (including mental and emotional health) in Roe v. Wade (and Doe v. Bolton), the Nebraska law breached these landmark rulings by failing to include an exception for the woman's health. In 2002, Rep. Steve Chabot introduced yet another ban on the procedure in the House, which passed and was placed on the Senate legislative calendar in late July of 2002 but, given the lateness in the year, was not scheduled for Senate action.

\section{The Partial-Birth Abortion Ban Act of 2003}

Passage of the bill. In February 2003, Sen. Rick Santorum introduced a ban on the procedure in the Senate (S.3). The novel feature of the 2003 bill, as distinct from previous bills, was that it directly challenged the Supreme Court's acceptance (in Stenberg v. Carhart, 2000) of findings from the lower court that a partial-birth abortion may be necessary to preserve the health of a woman. The 2003 bill presented factual findings that the procedure 'is never medically necessary' and can pose serious risks to women, ${ }^{24}$ and notes that the Supreme Court, by precedence, accords deference to congressional fact findings.

This was passed by the Senate with one amendment by Sen. Tom Harkin which expressed the Sense of the Senate that Roe v. Wade 'was appropriate' and 'should not be overturned'. Three other amendments failed to pass: Sen. Patty Murray sought to increase the availability of contraceptives, but her amendment was ruled out of order because it raised budgetary issues; Sen. Richard Durbin, sought a title change (to 'Late Term Abortion Limitation Act') and the insertion of a medical exception; and similarly, Sen. Diane Feinstein sought to change the title to the 'Post-Viability Abortion Restriction Act' and to insert a health exception. Notably, the bill was not committed to the Senate Judiciary Committee: on 12 March, Sen. Barbara Boxer moved to commit the bill but this motion failed 42 to $56 .^{25}$ The bill passed the House in June and the conference report was filed in late September. ${ }^{26}$ On 2 October 2003 the House agreed to the conference version of

\footnotetext{
${ }^{23}$ The president may reject (or veto) a bill passed by both houses of Congress. In rare circumstances, Congress may override a presidential veto, in which case the bill becomes law without the approval of the president. A two-thirds majority vote of the representatives and senators present is required to override a presidential veto.

${ }^{24}$ Partial-birth Abortion Ban Act of 2003, 18 USC, 1531, 108-105, sec. 2 (1, 2).

${ }^{25}$ Sen. Boxer and other opponents no doubt sought, at the minimum, to revise the bill in committee or stall its progress.

${ }^{26}$ A conference committee reconciles differences between the House and Senate versions of a bill. Once a compromise version is agreed by the committee, it prepares a report which details the proposed changes. Both the House and Senate must approve this report.
} 

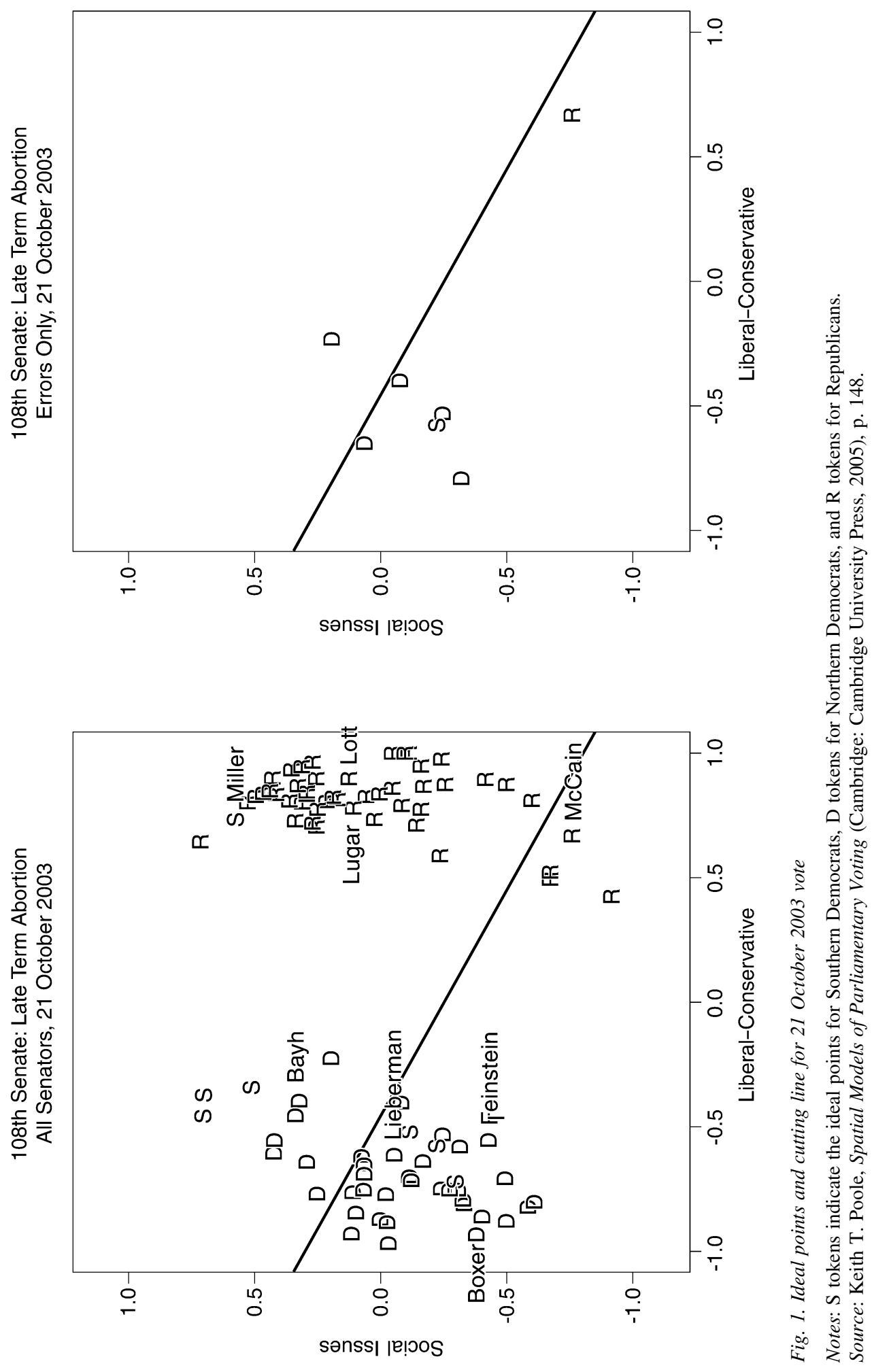
the bill (which now excluded the Harkin amendment that had passed the Senate), and in turn this was also agreed in the Senate (64-34) on 21 October. On 5 November President Bush signed the bill, and it became Public Law No: 108-105.

The Final Vote in NOMINATE. In terms of roll-call voting, abortion is seen as slowly becoming a liberal-conservative issue which can more easily be mapped into an existing left-right ideological (first) dimension. ${ }^{27}$ Poole describes the 21 October Senate vote as 'nearly one-dimensional' although a second dimension - on " "social" or "lifestyle" issues' - accounts for a small amount of the voting. ${ }^{28}$ His graphs of the ideal points for senators, along with the cutting line for this vote and the seven senators whose votes were incorrectly predicted, are presented in Figure 1. Since he finds that a second dimension is 'extremely weak' in the 108th Senate he interprets this vote as representative of a one-dimensional legislature. $^{29}$

While Poole's interpretation of the vote as mostly one-dimensional may be open to dispute (for example, the nearly 45 degree angle of the cutting line in Figure 1 seems to suggest that both dimensions contributed to the vote), the criticism of this article is that his focus is on the votes alone. Ultimately, senators voted on a particular form of this bill: their final vote was shaped and constrained by a deliberate framing of the bill and manipulation of choices available to senators on which to vote. Poole's one-dimensional interpretation of the vote is helpful in providing the overarching ideological framework, but it provides no insight into the issues at stake, the legislative strategies employed, and the framing arguments used to influence both the final vote and, more particularly, the anticipated judgment of Supreme Court justices.

\section{DATA AND METHODOLOGY}

\section{Data}

This article adopts a unique approach to bridging textual and voting data. The former consists of all the Senate floor debates on the Partial-Birth Abortion Ban Act of 2003 from March to the final vote on 21 October 2003 (see Table 1), while the latter consists of Poole's rank order of each senator for the 108th Congress (Table 2), ${ }^{30}$ plus the senator's party affiliation and vote on 21 October 2003. Poole notes that senators' party affiliations 'are almost perfectly separated in the liberal-conservative ordering ${ }^{31}$ with Barbara Boxer at 1.0 being the most liberal senator and Jon Kyl at 100 the most conservative. Table 2 also indicates with asterisks the senators that were misclassified by NOMINATE - and were thus 'errors' - in the 21 October 2003 vote on the bill. As noted earlier, deliberations on the bill occurred only on the floor of the Senate as it was never sent to the Judiciary Committee, and thus these debates provide a full depiction of the recorded arguments in the Senate on this bill.

In terms of the structure of the data, the debates form a single text file where each speech or interjection by a senator constitutes a 'case', and each is identified (or 'tagged') with

${ }^{27}$ Poole and Rosenthal, Congress, p. 113.

${ }^{28}$ Poole, Spatial Models of Parliamentary Voting, pp. 147-8.

${ }^{29}$ Poole, Spatial Models of Parliamentary Voting, p. 48.

${ }^{30}$ Keith Poole, '108th Senate Rank Ordering', (26 October 2004) < http://www.voteview.com/ > , accessed January 2006.

${ }^{31}$ Poole, '108th Senate Rank Ordering'. 
TABle $1 \quad$ Senate Debates On Partial-Birth Abortion Ban Act of 2003

\begin{tabular}{|c|c|c|}
\hline Subject & Date & Reference \\
\hline Partial-Birth Abortion Ban Act of 2003 & 10 March 2003 & pp. S3383-9 \\
\hline $\begin{array}{l}\text { Partial-Birth Abortion Act of } 2003 \\
\text { (continued) }\end{array}$ & 10 March 2003 & pp. S3390-9 \\
\hline Partial-Birth Abortion Ban Act of 2003 & 11 March 2003 & pp. S3422-9 \\
\hline $\begin{array}{l}\text { Partial-Birth Abortion Ban Act of } 2003 \\
\text { (continued) }\end{array}$ & 11 March 2003 & $\begin{array}{l}\text { pp. S3456-63 } \\
\text { (deleting } \\
\text { interruption of } \\
\text { debate to discuss } \\
\text { Iraq), and } \\
\text { pp. S3467-94 } \\
\text { (excluding } \\
\text { statistical tables) }\end{array}$ \\
\hline $\begin{array}{l}\text { Partial-Birth Abortion Ban Act of } 2003 \\
\text { (Durbin amendment No. 259, } \\
\text { in the nature of a substitute) }\end{array}$ & 12 March 2003 & pp. S3560-S3608 \\
\hline Partial-Birth Abortion Ban Act & 12 March 2003 & pp. S3644-7 \\
\hline Partial-Birth Abortion Ban Act of 2003 & 13 March 2003 & pp. S3653-62 \\
\hline The Right to Choose* & 15 September 2003 & pp. S11454-60 \\
\hline $\begin{array}{l}\text { Partial-Birth Abortion Ban Act of } 2003 \\
\text { (resumed) }\end{array}$ & 16 September 2003 & pp. S11551-7 \\
\hline Partial-Birth Abortion Ban Act of 2003 & 17 September 2003 & $\begin{array}{l}\text { pp. S11589-601 } \\
\text { (excluding } \\
\text { statistical table) }\end{array}$ \\
\hline Roe v. Wade $\dagger$ & 17 September 2003 & pp. S11601-5 \\
\hline $\begin{array}{l}\text { Partial-Birth Abortion Ban Act of } 2003 \\
\text { (Conference Report) }\end{array}$ & 21 October 2003 & pp. S12914-27 \\
\hline $\begin{array}{l}\text { Partial-Birth Abortion Ban Act of } 2003 \\
\text { (Conference Report, continued) }\end{array}$ & 21 October 2003 & pp. S12927-48 \\
\hline
\end{tabular}

*Included given its relevance and that it immediately precedes the resumption of the main debate.

$\dagger$ Included given its relevance and that it is temporally situated in close proximity to the main debate.

identifying characteristics, namely, (a) the senator's ideological rank and party affiliation (from Table 2) (b) the senator's vote on the final bill (yea, nay, abstain); and (c) the nature of the speech (either in the form of a statement/argument or as printed material read by the senator or requested for inclusion in the Record). ${ }^{32}$ The rationale for designating whether the speech derived from the senator's own words or from letters and the testimony of others is to seek to determine whether particular lines of argument were more likely to be associated with the use of outside material and whether any interpretation can be placed upon such an association.

\footnotetext{
${ }^{32}$ The debates were partially edited to exclude the frequent requests for time, statements by the clerk and the presiding officer, the reading of the bill and the calling of the roll.
} 
TABLE 2 List of Senators

\begin{tabular}{|c|c|c|c|c|c|c|c|}
\hline \multirow{2}{*}{$\frac{\text { Name }}{\text { Barbara Boxer }}$} & \multirow{2}{*}{$\begin{array}{l}\text { State } \\
\mathrm{CA}\end{array}$} & \multicolumn{2}{|c|}{ Party Rank } & \multirow{2}{*}{$\begin{array}{l}\text { Name } \\
\text { Susan Collins }\end{array}$} & \multirow{2}{*}{$\begin{array}{l}\text { State } \\
\text { ME }\end{array}$} & \multicolumn{2}{|c|}{ Party Rank } \\
\hline & & D & 1.0 & & & $\mathrm{R}$ & 51.0 \\
\hline Ed Kennedy & MA & D & 2.0 & Arlen Specter & PA & $\mathrm{R}$ & 52.0 \\
\hline Frank Lautenberg & NJ & $\mathrm{D}$ & 3.0 & George Voinovich & $\mathrm{OH}$ & $\mathrm{R}$ & 53.0 \\
\hline Jack Reed & RI & $\mathrm{D}$ & 4.0 & Mike Dewine & $\mathrm{OH}$ & $\mathrm{R}$ & 54.0 \\
\hline Jon Corzine & NJ & D & 5.0 & Gordon Smith & OR & $\mathrm{R}$ & 55.0 \\
\hline Ernest Hollings & $\mathrm{SC}$ & D & $6.0^{*}$ & Norm Coleman & MN & $\mathrm{R}$ & 56.0 \\
\hline Bob Graham & FL & D & 7.0 & Richard Lugar & IN & $\mathrm{R}$ & 57.0 \\
\hline Paul Sarbanes & MD & D & $9.5 \mathrm{a}$ & John Warner & VA & $\mathrm{R}$ & 58.0 \\
\hline James Jeffords & VT & I & $9.5 \mathrm{~b}$ & Pat Roberts & KS & $\mathrm{R}$ & $59.5 \mathrm{a}$ \\
\hline Tom Harkin & IA & $\mathrm{D}$ & $9.5 \mathrm{c}$ & Zell Miller & GA & $\mathrm{D}$ & $59.5 b$ \\
\hline Robert Byrd & WV & D & $9.5 \mathrm{~d}$ & Sam Brownback & $\mathrm{KS}$ & $\mathrm{R}$ & $61.5 \mathrm{a}$ \\
\hline Patrick Leahy & VT & D & $12.0^{*}$ & Ben Campbell & $\mathrm{CO}$ & $\mathrm{R}$ & $61.5 b$ \\
\hline Christopher Dodd & CT & $\mathrm{D}$ & 13.0 & Lisa Murkowski & AK & $\mathrm{R}$ & $63.5 \mathrm{a}$ \\
\hline Daniel Akaka & HI & D & $14.5 \mathrm{a}$ & Robert Bennett & UT & $\mathrm{R}$ & $63.5 \mathrm{~b}$ \\
\hline Carl Levin & MI & D & $14.5 b$ & Kay Hutchison & $\mathrm{TX}$ & $\mathrm{R}$ & 65.0 \\
\hline Richard Durbin & IL & D & 16.0 & Chuck Hagel & $\mathrm{NE}$ & $\mathrm{R}$ & $66.5 \mathrm{a}$ \\
\hline Daniel Inouye & HI & D & $17.5 \mathrm{a}$ & Saxby Chambliss & GA & $\mathrm{R}$ & $66.5 b$ \\
\hline Russell Feingold & WI & D & $17.5 b$ & James Talent & MO & $\mathrm{R}$ & 68.0 \\
\hline John Rockefeller & WV & D & 19.0 & Peter Fitzgerald & IL & $\mathrm{R}$ & 69.0 \\
\hline John Edwards & $\mathrm{NC}$ & D & 20.0 & Chuck Grassley & IA & $\mathrm{R}$ & $70.5 a$ \\
\hline John Kerry & MA & D & $21.5 \mathrm{a}$ & Elizabeth Dole & $\mathrm{NC}$ & $\mathrm{R}$ & $70.5 b$ \\
\hline Hillary Clinton & NY & $\mathrm{D}$ & $21.5 b$ & Thad Cochran & MS & $\mathrm{R}$ & 72.0 \\
\hline Barbara Mikulski & MD & $\mathrm{D}$ & 23.0 & Ted Stevens & AK & $\mathrm{R}$ & $73.5 \mathrm{a}$ \\
\hline Mark Dayton & $\mathrm{MN}$ & D & 24.0 & Richard Shelby & AL & $\mathrm{R}$ & $73.5 b$ \\
\hline Patty Murray & WA & D & $26.0 \mathrm{a}$ & William Frist & TN & $\mathrm{R}$ & $76.0 \mathrm{a}$ \\
\hline Debbie Stabenow & MI & $\mathrm{D}$ & $26.0 \mathrm{~b}$ & Christopher Bond & MO & $\mathrm{R}$ & $76.0 \mathrm{~b}$ \\
\hline Maria Cantwell & WA & D & $26.0 \mathrm{c}$ & Pete Domenici & NM & $\mathrm{R}$ & $76.0 \mathrm{c}$ \\
\hline Ron Wyden & OR & D & 28.0 & Mitch McConnell & KY & $\mathrm{R}$ & 78.0 \\
\hline Dianne Feinstein & $\mathrm{CA}$ & D & 29.0 & George Allen & VA & $\mathrm{R}$ & 79.0 \\
\hline Herb Kohl & WI & $\mathrm{D}$ & $30.5 a$ & Lamar Alexander & TN & $\mathrm{R}$ & 80.0 \\
\hline Bill Nelson & FL & D & $30.5 b$ & Orrin Hatch (Chair, Judiciary) & UT & $\mathrm{R}$ & 81.0 \\
\hline Charles Schumer & NY & $\mathrm{D}$ & $33.0 \mathrm{a}$ & Jim Bunning & KY & $\mathrm{R}$ & 82.0 \\
\hline Joseph Lieberman & CT & $\mathrm{D}$ & $33.0 \mathrm{~b}$ & Conrad Burns & MT & $\mathrm{R}$ & 83.0 \\
\hline Joseph Biden & $\mathrm{DE}$ & D & $33.0 \mathrm{c} *$ & Trent Lott & MS & $\mathrm{R}$ & 84.0 \\
\hline Jeff Bingaman & NM & $\mathrm{D}$ & 35.0 & Mike Crapo & ID & $\mathrm{R}$ & $85.5 \mathrm{a}$ \\
\hline Harry Reid & NV & D & $36.0 *$ & Larry Craig & ID & $\mathrm{R}$ & $85.5 b$ \\
\hline Tom Daschle & SD & $\mathrm{D}$ & 37.0 & James Inhofe & $\mathrm{OK}$ & $\mathrm{R}$ & 87.0 \\
\hline Tim Johnson & SD & D & 38.0 & John Cornyn & TX & $\mathrm{R}$ & 88.0 \\
\hline Byron Dorgan & ND & D & 39.0 & Craig Thomas & WY & $\mathrm{R}$ & 89.0 \\
\hline Kent Conrad & ND & $\mathrm{D}$ & 40.0 & Michael Enzi & WY & $\mathrm{R}$ & 90.0 \\
\hline Thomas Carper & $\mathrm{DE}$ & $\mathrm{D}$ & $41.0^{*}$ & Judd Gregg & $\mathrm{NH}$ & $\mathrm{R}$ & 91.0 \\
\hline Evan Bayh & IN & $\mathrm{D}$ & 42.0 & Lindsey Graham & $\mathrm{SC}$ & $\mathrm{R}$ & 92.0 \\
\hline Mark Pryor & AR & D & 43.0 & John Sununu & $\mathrm{NH}$ & $\mathrm{R}$ & $93.5 \mathrm{a}$ \\
\hline Blanche Lincoln & AR & D & 44.0 & Rick Santorum & PA & $\mathrm{R}$ & $93.5 b$ \\
\hline Mary Landrieu & LA & D & 45.0 & Wayne Allard & $\mathrm{CO}$ & $\mathrm{R}$ & 95.0 \\
\hline Max Baucus & MT & D & $46.0^{*}$ & John Ensign & NV & $\mathrm{R}$ & $96.5 a$ \\
\hline John Breaux & LA & $\mathrm{D}$ & 47.0 & John McCain & $\mathrm{AZ}$ & $\mathrm{R}$ & $96.5 b^{*}$ \\
\hline Benjamin Nelson & $\mathrm{NE}$ & D & 48.0 & Jeff Sessions & AL & $\mathrm{R}$ & 98.0 \\
\hline Lincoln Chafee & RI & $\mathrm{R}$ & 49.0 & Don Nickles & OK & $\mathrm{R}$ & 99.0 \\
\hline Olympia Snowe & ME & $\mathrm{R}$ & 50.0 & Jon Kyl & AZ & $\mathrm{R}$ & 100.0 \\
\hline
\end{tabular}

Notes: Members of Judiciary Committee in italic; *Error in NOMINATE. 


\section{Methodology: Computer-Assisted Content Analysis}

Computer-assisted content analysis in political science. Automated content analysis of political texts has captured the attention and imagination of political scientists, with researchers seeking to measure empirically the policy positions from political party manifestos and legislative speeches, ${ }^{33}$ the dynamics of political agenda-setting in Congress $^{34}$ and political culture, ${ }^{35}$ and to classify or extract meaning from political texts more generally. ${ }^{36}$

A variety of packages are on offer for automated content analysis, each providing its own array of analytical tools and insights into textual data. ${ }^{37}$ Some packages appear well-suited to analyse very large corpora encompassing multiple topics, but usually these require a pre-coded or pre-scaled reference document from which 'fixed parameters ${ }^{\text {, }}$ ' may be derived and employed on other documents (or the larger population of documents) to scale, code and/or classify these documents. ${ }^{39}$ Other approaches employ machine-learning in order to mitigate the costs of human labelling, although they recognize that human intervention to monitor and guide the analysis cannot be avoided. ${ }^{40}$ ALCESTE, the approach used here and elsewhere in the social sciences, ${ }^{41}$ does not require any pre-coding but is

${ }^{33}$ Matthew J. Gabel and John D. Huber, 'Putting Parties in Their Place: Inferring Party Left-Right Ideological Positions from Party Manifestos Data', American Journal of Political Science, 44 (2000), 94-103; Michael Laver and John Garry, 'Estimating Policy Positions from Political Texts', American Journal of Political Science, 44 (2000), 619-34; Michael Laver and Kenneth Benoit, 'Locating TDs in Policy Spaces Using Computer Word-scoring', Irish Political Studies, 17 (2002), 59-72; Michael Laver, Kenneth Benoit and John Garry, 'Estimating the Policy Positions of Political Actors Using Words as Data', American Political Science Review, 97 (2002), 311-31; Kenneth Benoit and Slava Mikhailov, 'Correcting the Error in the Comparative Manifesto Project Estimates' (paper presented at the Annual Meeting of the Midwest Political Science Association, Chicago, 2007); Jeremy Albright, 'Political Parties in Time and Space' (paper presented at the Annual Meeting of the Midwest Political Science Association, Chicago, 2007); and Jonathan Slapin and Sven-Oliver Proksch, 'A Scaling Model for Estimating Time-Series Policy Positions from Texts' (paper presented at the Annual Meeting of the Midwest Political Science Association, Chicago, 2007).

${ }^{34}$ Kevin M. Quinn et al., 'An Automated Method of Topic-Coding Legislative Speech Over Time with Application to the $105^{\text {th }}-108$ th U.S. Senate' (unpublished manuscript, 18 July 2006).

${ }^{35}$ G. David Garson, 'Researching and Teaching Political Culture through Web-Based Content Profile Analysis' (paper presented at the Annual Meeting of the American Political Science Association, Boston, Mass., 2002).

${ }^{36}$ See the following papers presented at the Annual Meeting of the Midwest Political Science Association, Chicago, 2007: Daniel Hopkins and Gary King, 'Extracting Systematic Social Science Meaning from Text'; Dustin Hillard, Stephen Purpura and John Wilkerson, 'An Active Learning Framework for Classifying Political Text'; Burt Monroe, Kevin Quinn and Michael Colaresi, 'Legislative Rhetoric and Heresthetics'; Jean-François Godbout, Daniel Diermeier, Bei Yu and Stefan Kaufman, 'Automated Text Classification of Senatorial Speech in the 101st-109th Congresses for Ideological Vocabulary Extraction and Position Prediction'.

37 For a recent showcase of these approaches in political science, see $<$ http://www.purpuras.net/apsagroup/ $>$.

38 Will Lowe, 'Understanding Wordscores" (paper presented at the Annual Meeting of the Midwest Political Science Association, Chicago, 2007).

39 Some examples include Laver et al., 'Estimating the Policy Positions of Political Actors', and Hopkins and King, 'Extracting Systematic Social Science Meaning from Text'.

40 Dustin Hillard et al., 'An Active Learning Framework for Classifying Political Text'.

${ }^{41}$ M. C. Noel-Jorand, M. Reinert, M. Bonnon and P. Therme, 'Discourse Analysis and Psychological Adaptation to High Altitude Hypoxia’, Stress Medicine, 11 (1995), 27-39; M. C. Noel-Jorand, M. Reinert, S. Giudicelli and D. Dassa, 'A New Approach to Discourse Analysis in Psychiatry, Applied to Schizophrenic Patient Speech', Schizophrenia Research, 25 (1997), 183-98; M. C. Noel-Jorand, M. Reinert, S. Giudicelli and D. Dassa, 'Schizophrenia: The Quest for a Minimum Sense of Identity to Ward Off Delusional Psychosis', Canadian Journal of Psychiatry, 49 (2004), 394-8; L. Lahlou, 'A Method to Extract Social Representations from Linguistic Corpora', 
more limited in that it cannot analyse very large corpora or corpora containing multiple discrete topics. ${ }^{42}$ Its chief advantage for the Senate debates on abortion is that it allows the researcher to analyse statistically and spatially the intersection of characteristics of the speakers (e.g., party affiliation, vote on the bill and ideological rank) with the tendency of those speakers to develop and focus on particular lines of argument. A more detailed description of the ALCESTE method is given in Appendix 1.

\section{RESULTS OF ANALYSIS OF SENATE DEBATES}

\section{Identifying the Themes}

Table 3 provides a summary of the basic statistics from ALCESTE. The total word count for the text file is 257,999 and, of these, 107,065 were unique words that were analysed by the program. ${ }^{43}$ The passive variables (also referred to as tagged indicators) define characteristics of each speech or 'case', and these include the senator's rank, party affiliation, final vote on the bill and so on. ${ }^{44}$ In total, there were fifty-nine unique tags.

TA B LE 3 ALCESTE Analysis: Basic Statistics for Senate Debates on Partial-Birth Abortion Ban Act of 2003

Total word count

Unique words analysed

Passive variables (tagged indicators)

ICUs ( $=$ number of speeches)

Classified ECUs

Lexical classes

Distribution of classes (\%)

\author{
257,999 \\ 107,065 \\ 59 \\ 479 \\ $4,907(=78 \%$ of the retained $\mathrm{ECU})$ \\ 4 \\ 1. Choice, Rights \& Morality (35.9) \\ 2. Constitutionality (27.5) \\ 3. Personal Experiences (woman's health versus \\ fetal life) (21.0) \\ 4. Legislative Procedure (15.6)
}

\footnotetext{
(F'note continued)

Japanese Journal of Experimental Social Psychology, 36 (1996), 278-91; Nicholas C. Allum, 'A Social Representations Approach to the Comparison of Three Textual Corpora Using ALCESTE' (MSc dissertation, London School of Economics and Political Science, 1998); Mathieu Brugidou, 'Epitaphes, l'image de François Mitterrand à travers l'analyse d'une question ouverte posée à sa mort' (Epitaphs. Francois Mitterrand's Image: An Analysis of an Open Question Asked on His Death), Revue Française de Science Politique, 48 (1998), 97-120; Mathieu Brugidou, 'Les discours de la revendication et de l'action dans les éditoriaux de la presse syndicale (1996-1998)' (The Discourse of Demands and Action in [French] Trade Union Press Editorials (1996-1998)), Revue Française de Science Politique, 50 (2000), 967-92; Andrew Bailey and Cheryl Schonhardt-Bailey, 'Explaining the Volcker Revolution of 1979: Testing Theories with Transcripts' (paper presented at the Annual Meeting of the American Political Science Association, Washington, D.C., 2005); Andrew Bailey and Cheryl Schonhardt-Bailey, 'Policy Shaping Politics; Monetary Policy Deliberations in Congressional Hearings' (paper presented at the First World Meeting of the Public Choice Society, 2007); Cheryl Schonhardt-Bailey, From the Corn Laws to Free Trade: Interests, Ideas and Institutions in Historical Perspective (Cambridge: MIT Press, 2006).

42 Although subsequent versions may allow a larger corpus, ALCESTE 4.7 requires that the corpus not exceed $15 \mathrm{mb}$.

${ }^{43}$ Plurals and conjugation endings are reduced to a single form and nonce words are eliminated from the analysis. This leaves a smaller word count which is analysed by the program.

${ }^{44}$ These are deemed 'passive' as they do not contribute to either the calculation of the word classes or the factors in the correspondence analysis.
} 
The 'Initial Context Unit', or ICU, is essentially the sampling unit - i.e., a pre-existing division of the text and is specified by the user. I have referred to ICUs as cases, or the speeches of senators, and we can see that there were 479 speeches on the bill over the period from March 2003 to October 2003. The 'Elementary Context Unit', or ECU, is a 'gauged sentence', which the program automatically constructs based upon word length and punctuation in the text. ${ }^{45}$ Using the presence or absence of words in each ECU, the program calculates matrices on which to build the classification process. The program conducts two preliminary analyses, each using slightly different lengths for the contextual unit. ${ }^{46}$ It then opts for the length that allows the greater proportion of ECUs to be successfully classified, relative to the total available. From Table 3 we can see that 4,907 ECUs were classified, equating to 78 per cent of the ECUs.

The final two rows in Table 3 indicate the number of classes identified and the size of each class (as measured by the percentage of the total ECUs classified within each). In total, four classes are identified in the Senate debates on the PBA Ban bill. The labels for each class (such as Choice, Rights \& Morality, and so on) are not, however, automatically given by the program.

The output provides the researcher with a number of different tools for conceptualizing the content of classes. Of the many tools, two are particularly useful - characteristic words and characteristic ECUs. ${ }^{47}$ The most characteristic "meaningful words ${ }^{48}$ for each class, along with their $\chi^{2}$ statistical significance ${ }^{49}$ (with the minimum $\chi^{2}$ value for selection set at 16.36 for this analysis, with 1 degree of freedom (df)), ${ }^{50}$ provide an indication of the theme or frame of argument that unifies a class. The most characteristic words for each class are those with the highest $\chi^{2}$ values. Words ending with ' + ' indicate that these are reduced forms (for example, 'want+' may refer to want, wanted or wants).

45 Popping notes that the ECU is akin to the 'recording unit' used in other programs, where it is usually defined by the researcher (Roel Popping, correspondence with author, 29 October 2004).

${ }^{46}$ A contextual unit is equivalent to one or more successive ECU(s). The two calculations are done with two different parameters for the selected number of words per contextual unit in order to check the reliability of the classes and the stability of the results (Max Reinert, ALCESTE Users' Manual, 4.0 Pro (English version) (Toulouse: Image, 1998).

47 The standard report lists the top twenty ECUs for each class, ranked by $\chi^{2}$ association. However, a separate file is produced that lists all the ECUs for each class, where the default cut-off for selection is 0 .

48 Meaningful words are nouns, verbs, adjectives and some adverbs. These comprise 'the vocabulary of the corpus' and are used to calculate the classes. Function words (because, where, as and so on) are recognized by the internal dictionary and are required for syntax, but - like the tagged indicators - are not used in the calculation of classes. (Reinert, ALCESTE Users' Manual, p. 12) For a table of the levels of $\chi^{2}$ values for words, which may then be used in conjunction with a standard $\chi^{2}$ table, see Reinert, ALCESTE Users' Manual, p. 41.

${ }^{49}$ Using descending hierarchical classification, ALCESTE creates two binary tables (or two classifications) which are then compared. The ECUs that are retained for analysis are those found in both classifications - a process which effectively creates a stable level of partitioning. The stability of the partitioning is measured by constructing a table of co-occurrence, which is the cross between the partition obtained in the first classification and the partition obtained in the second classification. The result is a 'signed $\chi^{2}$ table' - that is a data table with the positive and negative links between the classes. This signed table is used to test the statistical significance of the table of co-occurrence, where 'a high positive chi-square indicate(s) a strong positive link (a chance occurrence would be expected to be less), a high negative chi-square, a strong negative link (a chance occurrence would be expected to be more)' ( Reinert, ALCESTE Users' Manual, pp. 26-7).

${ }^{50}$ This minimum value for word selection within ALCESTE varies from 2.13 to 20, with smaller text files tending towards the lower threshold and larger ones towards the high threshold. The basic rule of thumb with ALCESTE is (as with any statistical analysis) - the more data, the easier it is to attain statistical significance (hence larger text files have to attain a higher threshold to be statistically significant). 
The top most representative words (and $\chi^{2}$ values) for Class 1 are people $+(335)$, right $+(194)$, think (188), country (175), we (140), want $+(131), I(128)$, say (102), society, (96) and what (94). While these words provide an initial impression of the theme of the class - i.e., what 'we' or 'I' think is 'right' for 'people', 'society', or the 'country' - a scan through the representative ECUs is more informative. The top twenty ECUs for this class are fairly evenly divided between the opponents and the supporters of the bill, with each constructing his/her argument around the basic tension between a woman's 'right to choose' and the 'morality' of abortion. The focus of this class is less on the specifics of the $\mathrm{D} \& \mathrm{X}$ procedure and more on underlying conflict of views on abortion in general and, in this sense, this class captures the two basic frames in the abortion debate - i.e., the pro-choice frame 'about' a woman's right to choose and the pro-life frame 'about' unborn babies and the morality of protecting life. ${ }^{51}$ In a more empirical light, the class forms what might be construed in regression terms as the constant or the intercept.

ECUs that are typical of the arguments made by opponents of the bill highlight the importance of a woman's choice ( $\chi^{2}$ values are in brackets, with $1 \mathrm{df}$ and the hash mark indicates representative words of Class 1 within each ECU):

(33) That is what \#Roe was, a very \#balanced \#decision. It \#says: if you \#want to \#go through with this pregnancy, \#absolutely that is your \#right, but if you do not, in the \#early stages it \#says to \#women: we \#respect you enough, we \#give you that \#dignity; we \#trust you enough to \#make that \#decision. [Barbara Boxer]

(24) It is the Republican leadership that repeatedly \#wanted to restrict a woman's \#right to \#choose. It is the Republican leadership that \#says the language of \#Roe v. \#Wade is \#extreme, and that every woman in \#America \#ought to \#understand that, \#especially \#young \#women whose \#lives are \#ahead of them, who have grown \#up with more \#freedom ... [Tom Harkin]

ECUs that are representative of the bill's proponents (and in particular, the bill's sponsor, Sen. Rick Santorum) focus on the imperative of members of Congress to enact policies that are, in their view, moral. More broadly, proponents conceptualized moral decisions as falling within the realm of congressional responsibility and not merely the purview of the Supreme Court. Indeed Santorum's remarks reflect one theory of congressional responsibility, namely that members of Congress, as elected representatives, are better suited to interpret the moral sentiments of the American public than the courts and, as such, 'should share in the handling of constitutional questions.

(23) This is an \#evil in our midst. One of the \#great \#things I \#believe about \#America and about my colleagues is when they \#see \#evil, they have the \#courage to \#stand \#up and \#fight it. [Rick Santorum]

(24) Some \#people have \#come \#up to me for \#years and \#said: you don't have the \#right to \#make this \#moral \#decision. My response is: \#well, if I, as your \#elected representative, don't have the \#right, what \#gives the \#right to nine unelected \#judges to \#make this \#decision for you? [Rick Santorum]

The tags for each speech (senator's name, party, vote and so on) provide insight as to which variables were highly associated with particular themes. These tags obtain statistical significance according to their $\chi^{2}$ value (with $1 \mathrm{df}$ ): over 3.84 for 10 per cent; over 6.63 for 5 per cent; and over 10.8 for 1 per cent. For Class 1, Senators Brownback, Harkin and

51 Burns, The Moral Veto, pp. 10-11.

52 Morgan, Congress and the Constitution, p. 11. 
Clinton are highly significant (with $\chi^{2}$ values of 78,41 and 36 , respectively), and the 'statement' tag - which signifies that senators crafted their own arguments rather than relying on printed material from others - obtains a value of 235 .

For Class 2, ten of the top fifteen most representative words are medical $+(457)$, health $+(454)$, court $+(335)$, necessary (320), abortion $+(286)$, except $+(263)$, viability (261), supreme (244), procedure (226) and unconstitutional (201), suggesting a theme centred around the issue of whether or not a bill on an abortion procedure that lacks an exception for the health of the woman is constitutional. All but one of the top twenty ECUs are from opponents of the bill, who essentially argue that the bill is no different from the previous Nebraska law, and consequently can be expected to be ruled unconstitutional by the Supreme Court:

(39) ... \#Carhart that a \#Nebraska \#state \#law that \#bans \#certain \#abortion \#procedures is \#unconstitutional. The \#Supreme \#Court \#ruled it was \#unconstitutional for two \#reasons. First, it did not \#include an \#exception for a \#woman's \#health. \#Second, it does not \#clearly \#define the \#procedure it aims to \#prohibit and would \#ban other \#procedures, sometimes \#used early in pregnancy. [Barbara Mikulski]

(37) ... \#furthermore, the \#current \#ban \#fails to \#meet the \#provisions \#set \#forth by the \#Supreme \#Court in \#Stenberg v. \#Carhart, a \#ruling that overturned a \#Nebraska \#statute \#banning \#abortion because it \#contained no \#life and \#health \#exception for the \#mother. [Barbara Boxer]

One Republican senator who voted with the Democrats against the ban (and who, given Poole's ideological ranking of 51, could be described as a weak Republican) is Susan Collins. As a representative ECU for the constitutional argument, her statement provides a good example of a moderate Republican who opposes all late-term abortions, but nonetheless remains committed to the Supreme Court rulings requiring the medical exception:

(32) \#Let me be \#clear from the outset that I am strongly \#opposed not just to \#partial \#birth \#abortions, but to all late \#term \#abortions. I agree they should be \#banned. Such a \#ban, however, must have an \#exception for those \#rare \#cases when it is \#necessary to \#save the \#life of the \#woman or to \#protect her \#physical \#health from \#grievous harm. [Susan Collins]

Amidst the top twenty representative ECUs for this class, only one was from a Republican supporter of the bill, who reiterated the lack of medical necessity for the procedure and argued that it was unambiguous in banning just D \& X (and could not be construed as banning other procedures, such as D \& E):

(30) ... is never \#necessary to \#protect the \#health of the \#mother. \#Let me \#repeat, the \#carefully drafted \#definition \#used in S.3 for \#partial \#birth \#abortion cannot be construed to \#include any \#abortion \#procedure other than the D and X \#procedure. [Jim Bunning]

Highly significant tags for Class 2 include Senators Feinstein, Mikulski and Cantwell (with $\chi^{2}$ values of 149,50 and 38 , respectively - all at 1 per cent). Other statistically significant tags for this class include (a) senators voting 'nay' on the final vote, (b) Democratic senators, and (c) the tendency to rely on outside printed material (with $\chi^{2}$ values and significance of 15 ( 1 per cent), 8 ( 5 per cent), and 21 ( 1 per cent), respectively).

For Class 3, ten of the top fifteen words (and $\chi^{2}$ values) are deliver $+(533)$, baby (480), brain+(366), baby'+(287), head+(256), skull+(242), cervix (234), labor (232), scissor $+(230)$, and dilat $+(203)$. These characteristic words are indicative of the content 
of the class, namely descriptions of the D \& X procedure itself. The ECUs refine our understanding of this class by suggesting that while senators in favour of the ban described the gory details of the procedure and provided individual stories for an emotive punch, senators against the ban similarly invoked detailed stories of women in later stages of pregnancies who resorted to abortions rather than risk serious medical complications for themselves or when the fetuses were seriously deformed. The word content of this class illustrates the distinct frames employed by the pro-life and pro-choice camps: pro-life advocates argue that the issue 'is about unborn babies' while pro-choice advocates maintain that it is about a woman's right to terminate a pregnancy, ${ }^{53}$ and particularly in this case, where the health of the woman or of the fetus may be in question. ${ }^{54}$

Proponents of the bill described the procedure provocatively and with language of the pro-life frame (for example, substituting 'baby' for 'fetus'):

(65) ... and just a few \#inches from a \#completed birth, the physician uses an \#instrument such as a \#pair of \#scissors to \#tear or \#perforate the \#skull. The physician will then either crush the \#skull or will use a \#vacuum to \#remove the \#brain and other intracranial \#contents from the \#fetal \#skull, \#collapse the \#fetus's \#head and \#pull the \#fetus from the \#uterus. [George Voinovich]

(65) The \#doctor \#opened up the \#scissors, \#stuck a \#high powered \#suction \#tube \#into the \#opening, \#sucked the \#baby's \#brains \#out. Now the \#baby went \#completely limp. He \#cut the \#umbilical \#cord and \#delivered the \#placenta. He threw the \#baby in a pan along with the \#placenta and the \#instruments he had just used. [Mike DeWine]

Opponents of the bill countered with gruesome stories of deformities and complicated pregnancies:

(69) Vicki talked about having two children and a \#third \#child on the way. Here she was, late in her \#pregnancy. She \#described the \#pregnancy as disgustingly \#normal. At 32 \#weeks in the \#pregnancy, 8 \#months \#into the \#pregnancy, she went in for an \#ultrasound and \#discovered the \#little \#boy she was \#carrying had at least 9 \#major \#anomalies, \#including a \#fluid \#filled cranium with no \#brain \#tissue at all, compacted, ... [Richard Durbin]

(54) 'My \#doctor sent me to \#several \#specialists, \#including a \#perinatologist, a \#pediatric radiologist, and a \#geneticist, in a \#desperate attempt to find a way to save her. But everyone agreed, she would not \#survive \#outside of my \#body. They also \#feared that as the \#pregnancy \#progressed, before I went \#into \#labor, she would \#probably \#die from the \#increased compression in her \#brain.' [Barbara Boxer]

53 Burns, The Moral Veto, pp. 10-11.

54 The growing literature on 'framing' examines the role of ideas in structuring choices (James N. Druckman, 'On the Limits of Framing Effects: Who Can Frame?' Journal of Politics, 63 (2001), 1041-66; James N. Druckman, 'Political Preference Formation: Competition, Deliberation, and the (Ir)relevance of Framing Effects', American Political Science Review, 98 (2004), 671-86; Shanto Iyengar, 'Speaking of Values: The Framing of American Politics', The Forum (Berkeley Electronic Press [bepress]), 3, 3, art. 7 (2005); Hank Johnston and John A. Noakes, Frames of Protest: Social Movements and the Framing Perspective (Lanham, Md.: Rowman \& Littlefield, 2005)). Equating framing strategies with those of heresthetics, Druckman explains that both entail shifting the emphasis of a policy proposal from one set of beliefs to another set of beliefs (Druckman, 'On the Limits of Framing Effects', pp. 1044, 1046). Persuasion along a single dimension (or within a single frame) is quite different. An individual may be persuaded towards one or the other end of the dimension/frame, but this reflects a movement within a given spectrum of beliefs (for example, from liberalism to conservatism). Heresthetics, or framing effects, would entail a change of beliefs rather than a movement along a given spectrum. 
The single senator with a very high $\chi^{2}$ value for this class is Barbara Boxer, with 66 (1 per cent). Other significant tags for individual senators include a mixture of strong opponents to the bill (Corzine $\chi^{2}=27$ ( 1 per cent); Stabenow $\chi^{2}=11$ ( 1 per cent); and Clinton $\chi^{2}=5$ (10 per cent)) and strong supporters (Santorum $\chi^{2}=4$ (10 per cent); Frist $\chi^{2}=7$ (5 per cent); Allard $\chi^{2}=7$ (5 per cent); and Ensign $\chi^{2}=5$ (10 per cent)). The very large $\chi^{2}$ value of 512 for the 'printed material' tag signifies that senators were highly reliant upon letters and statements from outsiders (much of it describing personal experiences) for the content of this class. Finally, while small in comparison the Republican party tag is nonetheless significant at 10 per cent with a $\chi^{2}$ value of 4.

For Class 4, ten of the top fifteen most representative words (and $\chi^{2}$ values) are senate $+(687)$, president $+(682)$, house $+(432)$, floor $(423)$, vote $+(415)$, yield $+(401)$, committee $+(395)$, senator $+(307)$, motion $+(238)$, and amend $+(200)$. This thematic class focuses on the process of the legislation, but particularly two quite contentious aspects of the bill: first, its failure to be considered by the Senate Judiciary Committee, and second, the attempt by the House and the subsequent success of the conference to exclude the Senate-approved Harkin Amendment (supporting Roe v. Wade).

In March, Democrats rallied around Boxer's motion to commit, but so did a few Republicans, notably, Patrick Leahy:

(68) \#Mr. \#President, when \#Senator Santorum \#introduced S.3 on February 14, the \#leadership immediately placed the \#bill on the \#Senate legislative calendar, \#bypassing \#committee \#consideration of the \#bill. I \#rise \#today to \#support the \#motion to \#commit the \#bill for \#consideration by the \#Judiciary \#Committee. \#Senators deserve the \#benefit of full \#consideration and vigorous \#debate before they are \#asked to cast a \#vote on such a significant and complicated \#issue. [Patrick Leahy]

Following on from this ECU in the text, Leahy argued that since the last consideration of this issue by the Judiciary Committee (in 1997), 'there has been judicial review of similar legislation, including a Supreme Court decision, that should be fully vetted by the Judiciary Committee. The committee referral process is there for a reason and we ought to respect it.'

Santorum defended the Senate leadership's decision to bypass committee consideration by arguing on 10 March that the bill was 'unfinished business from last year' and that 'infirmities in the Nebraska statute' that resulted in the Supreme Court ruling had been addressed and remedied in the current bill:

(43) ... it is identical to the \#bill that is on the \#floor \#today. We \#asked for its \#consideration \#last year. I came to the \#floor on a \#couple of \#occasions and \#asked for \#unanimous \#consent to \#bring this \#bill forward. [Rick Santorum]

In his view, the bill had made clear which procedure was to be banned and had provided a stronger case against the need for a health exception. Congress had a 'right', moreover, to deferential treatment from the Supreme Court because of its ability to provide a 'more exhaustive study' through hearings and deliberations. In short, the Court had made 'a horrible decision' in the Nebraska case and he saw this bill as a means to rectify that error.

The second aspect of this Legislative Procedure class reflects the frustration of the bill's opponents at the attempt by the House to strip away the Senate-approved Harkin amendment, which reaffirmed support for Roe v. Wade:

(74) \#Mr. \#President, I \#express my cooperation, \#sense of solidarity with my \#colleague from \#California, \#Mrs. \#Boxer, and others under very unusual procedural circumstances. In my 
almost 24 years in the \#Senate, I cannot recall ever \#rising to \#speak on a \#motion to \#disagree with a \#House \#amendment on a \#Senate \#bill and \#request a \#conference. [Christopher Dodd]

The Senate voted $93-0$ on 17 September to disagree with the House amendment, and a conference was arranged, with Hatch, DeWine, Santorum, Feinstein and Boxer appointed as conferees (and the Speaker later added Chabot and Lofgren). To the anger of many Senate Democrats, the conference version of the bill excluded any support for Roe v. Wade. The Rules Committee subsequently waived points of order that were raised against the report, and thus the final bill no longer contained the Harkin amendment supporting Roe v. Wade.

One of the top representative ECUs from this class (by Boxer) flags this dispute over the Harkin amendment as core to this class:

(44) There we are. We are sitting in a \#conference \#committee. Here is where we are. The \#House and the \#Senate \#passed different \#bills. What was different about our \#bill, S.3? \#Senator \#Harkin put in \#language, and the \#Senate \#voted on it \#twice - \#twice: once was \#unanimous, once was a \#majority to keep Roe v. ... [Barbara Boxer]

Using this ECU as an indicator of key sections within the debates in which senators battled to shape the choices available in the final vote, it is worth examining more fully Boxer's disparaging remarks about the conference committee (which follow on from the above ECU):

So I come to the conference committee ready, along with Senator Feinstein, and other Congress people, to debate this issue. After all, my friend says here, we don't have any problem with Roe. This has nothing to do with Roe. Fine. Let's keep it in the bill, folks, a sense of the Senate that Roe v. Wade should not be overturned. The Senate voted for it twice. Let me tell you how long it took them to kick that amendment out. It was about 5 minutes. Not even a real discussion, not even a discussion about an amendment that passed this Senate twice ...

The single senator with a high $\chi^{2}$ value for Class 4 is Harry Reid, with $\chi^{2}=76$ ( 1 per cent). In 2003 Reid was the Democratic whip but in 2004 became the Senate Democratic Leader, and thus his prominence in speaking to this Legislative Procedure class is not surprising. More intriguing is that Reid is an error in NOMINATE - i.e., incorrectly predicted to vote against the bill. A number of other individual senators are significant for this class (Lautenberg $\chi^{2}=25$ ( 1 per cent); Voinovich $\chi^{2}=17$ ( 1 per cent); Feingold $\chi^{2}=14$ ( 1 per cent)), but more notably, other significant tags are the yeas on the final bill $\left(\chi^{2}=6\right.$ (10 per cent)) and the obvious reliance on statements rather than printed material when arguing on Legislative Procedure $\left(\chi^{2}=117\right.$ (1 per cent)).

Before examining the relationships between the classes, it is worth highlighting the strong tendency of speakers addressing the theme of Choice, Rights \& Morality (Class 1) to rely on their own arguments rather than letters or speeches of others, and conversely the even stronger tendency of those focusing on the Personal Experiences theme (Class 3 ) to rely on the words of others (i.e., printed material). There also appears to be a difference in the extent to which proponents versus opponents relied on statements over printed material. Of the 479 total speeches, 204 were from senators voting yea and 272 from senators voting nay (with one senator abstaining). Of the yeas, 95 per cent relied on their own statements and 5 per cent on printed material. Of the nays, 86 per cent relied on statements and 14 per cent on printed material. This seems to suggest that supporters of the ban were more content to construct their speeches more independently from the letters and testimony of others, while opponents of the ban were slightly more dependent on external sources of material for their speeches. 


\section{Linkages Between the Classes}

We have, thus far, gained some understanding of the main themes in the Senate debates on the PBA Ban Act. By identifying these themes we can uncover the arguments used by the bill's proponents who, seeking to appease the Supreme Court, manœuvred the carefully-crafted ban through the legislative process. Next, we seek to explore the relationships between the classes, and merge them with the complexity of the final roll-call vote in order to see how most of the bill's opponents chose to legitimize their votes along the constitutional dimension, steering clear of more emotionally charged rhetoric. ALCESTE provides us with two ways to gauge the relationships between the classes: tree graphs and correspondence analysis.

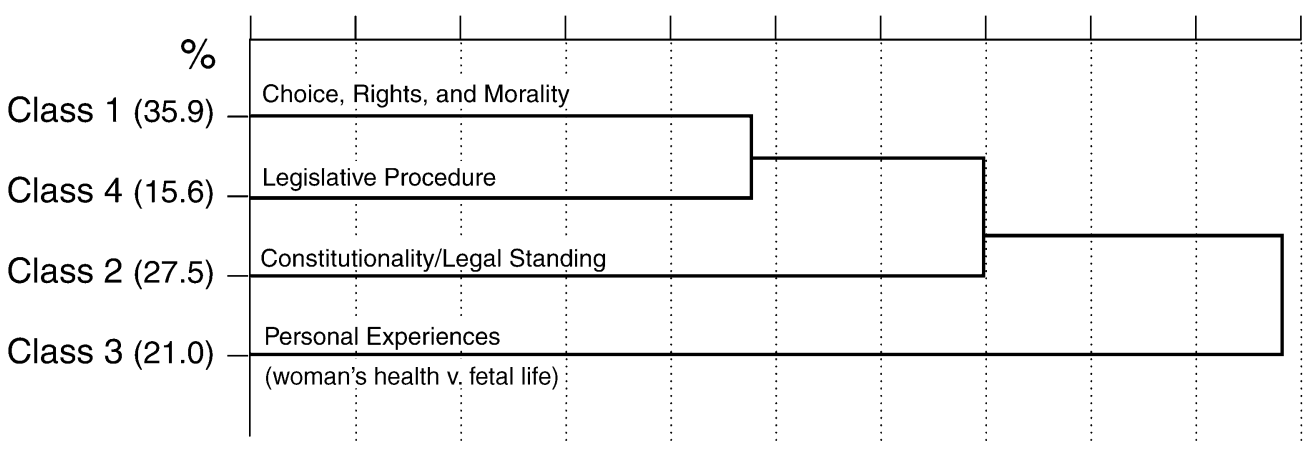

Fig. 2. Senate debates on Partial-Birth Abortion Ban Act of 2003 - tree graph of the stable classes

Tree graph. Figure 2 is a tree graph of the thematic classes, schematized according to ALCESTE's descending hierarchical classification procedure (the percentage weight given to each class by the analysis is indicated in parentheses). Beginning at the 'trunk' of the tree (from right to left - that is, from least related classes to most related classes), we can see that the speeches contain two basic forms of argumentation. The first (Class $3-$ Personal Experiences: a woman's health $v$. fetal life) highlights the highly emotive and graphically disturbing descriptions of the D \& X procedure itself and of women who underwent late-term abortions, as given by senators in personal histories. The word content of this class is evocative, graphic, personal and undeniably disturbing, and thus is distinct from the other themes of the Senate debates on this bill. Class 2 is the second most distinct class in terms of word content, with the thrust of senators' arguments on this theme levelled against the constitutionality of an abortion bill that contained no exception for a woman's health. Finally, Classes 1 and 4 can be said to be the least distinct of the four, which is not surprising since senators' more general remarks about abortion (Class 1) and the central role for Roe v. Wade in the manœuvrings of the legislative process (Class 4) provide plenty of scope for overlapping words. (Another way to interpret the overlap between these classes is to note that, inasmuch as Roe has set the stage for the conflict between the pro-life and pro-choice camps, it is not surprising to find this theme closely associated with the verbal clash between proponents of the two basic frames.)

The overall percentage distribution of the content of the classes indicates that choice and morality - the two basic frames of the abortion debate - consume about one-third of senators' time and energy. The remaining two-thirds of the verbal conflict in the 2003 bill 
appears to be unique to that bill - i.e., the specific procedural measures, the constitutionality of the absent health exception, and the gruesome medical details of the procedure are all unique to the PBA ban as defined in the 2003 bill. Hence, to ignore the content of the debates by focusing solely on the final roll-call vote is to miss much of what concerned senators about this particular bill. To see this more clearly, we turn to Figure 3, in which the results from ALCESTE's classification are represented in correspondence space.

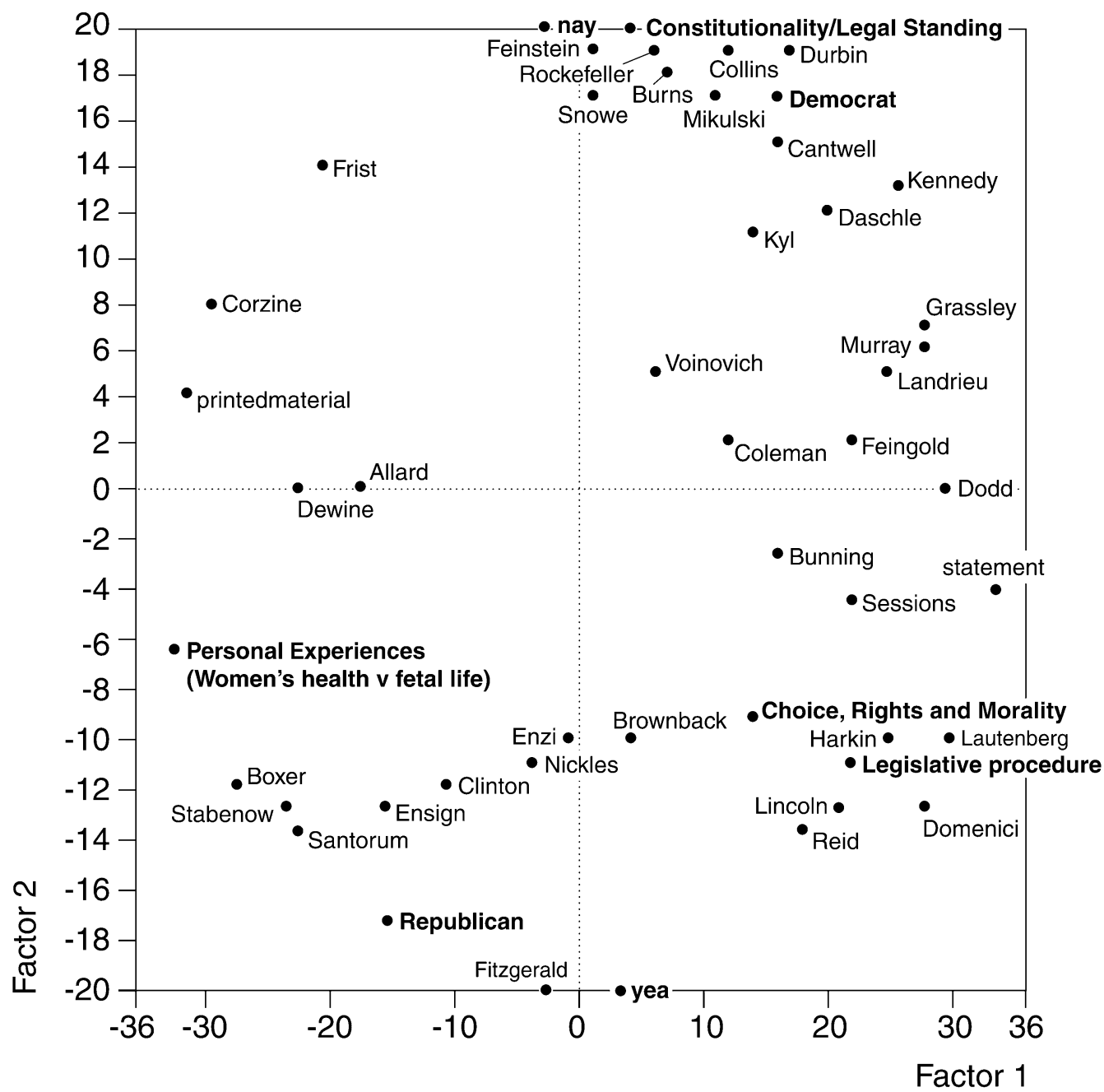

\begin{tabular}{|l|l|l|l|} 
& Eigenvalue & \% Association & \% Cumulative \\
\hline Factor 1 & 0.30 & 44.4 & 44.4 \\
Factor 2 & 0.22 & 32.9 & 77.3 \\
\hline
\end{tabular}

Fig. 3. Correspondence analysis of classes and tags from Senate debates on Partial-Birth Abortion Ban Act 
Correspondence analysis. The program cross-tabulates classes and words in their root form in order to create a matrix that can then be subjected to factor correspondence analysis. ${ }^{55}$ In this way, we obtain a spatial representation of the relations between the classes. The positions of the points is contingent on correlations rather than co-ordinates, ${ }^{56}$ where distance reflects the degree of co-occurrence. ${ }^{57}$ With respect to the axes, correspondence analysis aims to account for a maximum amount of association along the first (horizontal) axis. ${ }^{58}$ The second (vertical) axis seeks to account for a maximum of the remaining association, and so on. Hence, the total association is divided into components along principal axes. The resulting map provides a means for transforming numerical information into pictorial form. It provides a framework for the user to formulate her own interpretations, rather than providing clear-cut conclusions. ${ }^{59}$

Figure 3 presents a map of the correspondence analysis of the classes and tags for the Senate debates on the bill superimposing classes and tags on a single graph - where distance between a class and a tag (or between two classes) reflects the degree of association. (A second correspondence map provides the dispersion of characteristic words around the centre point of each class. This is given in Appendix 2, Figure 4.)

Beneath the correspondence map are the percentage associations for each factor, with the first accounting for 44.4 per cent and the second accounting for an additional 32.9 per cent. Hence, a two-dimensional correspondence space accounts for 77.3 per cent of the total variation in the corpus. ${ }^{60}$ Yet, dimensionality in this context requires careful dissection and analysis before a coherent picture may be obtained.

\footnotetext{
55 Michael Greenacre and Trevor Hastie, 'The Geometric Interpretation of Correspondence Analysis', Journal of the American Statistical Association, 82 (1987), 437-47; Michael J. Greenacre, Correspondence Analysis in Practice (London: Academic Press, 1993). While correspondence analysis is well established in the French literature (see J-P. Benzecri, L’Analyse des Données. Tome1: La Taxinomie. Tome 2: L'Analyse des Correspondances (Paris: Dunod, 1973), and the journal Cahiers de l'Analyse des Données), its use has spread with the publication of English applications (Michael J. Greenacre and L. G. Underhill, 'Scaling a Data Matrix in Low-dimensional Euclidean Space', in D.M. Hawkins, ed., Topics in Applied Multivariate Analysis (Cambridge: Cambridge University Press, 1982); Michael J. Greenacre, Theory and Applications of Correspondence Analysis (London: Academic Press, 1984); and Susan C. Weller and A. Kimball Romney, Metric Scaling: Correspondence Analysis (London: Sage, 1990)) and is occasionally used by political scientists (Jorg Blasius and Victor Thiessen, 'Methodological Artifacts in Measures of Political Efficacy and Trust: A Multiple Correspondence Analysis', Political Analysis, 9 (2001), 1-20). Correspondence analysis using numerical data is available in several major statistical packages, including BMDP, SPSS and SAS.

56 Reinert, ALCESTE Users' Manual, p. 45.

${ }^{57}$ For this, correspondence analysis uses the ' $\chi^{2}$ distance', which resembles the Euclidean distance between points in physical space. (Here, $\chi^{2}$ distance - which is distinct from the $\chi^{2}$ statistic used to measure the significance of the words and tags - can be observed in Euclidean space by transforming the profiles before constructing the plots.) In correspondence analysis, each squared difference between co-ordinates is divided by the corresponding element of the average profile (where the profile is a set of frequencies divided by their total). The justification for using the $\chi^{2}$ concept is that it allows one to transform the frequencies by dividing the square roots of the expected frequencies, thereby equalizing the variances. This can be compared to factor analysis, where data on different scales are standardized. For more detailed discussion and further geometric reasons for using the $\chi^{2}$ distance in correspondence analysis, see Greenacre, Correspondence Analysis in Practice, pp. 34-6.

58 Correspondence analysis usually refers to the 'inertia' of a table, which can also be called 'association' (Weller and Romney, Metric Scaling). A corresponding $\chi^{2}$ value can be obtained by multiplying the association value by the total $n$ of the table.

59 The association and $\chi^{2}$ statistic may be interpreted geometrically as the degree of dispersion of the set of rows and columns (or profile points) around their average, where the points are weighted.

${ }^{60}$ In total, three factors are identified in the correspondence analysis (with the third factor obtaining an eigenvalue of 0.16 and association of 22.7 per cent). (Usually, the dimensionality of the system is one less than the number of classes in the profile (Greenacre, Correspondence Analysis in Practice, p. 14).)
} 
From Figure 3 we can observe first that the horizontal axis mirrors the cleavage between the Personal Experiences class and the other three classes that we observe in the tree map (Figure 2) - that is, the Personal Experiences class falls at the far left while the other three fall to the right of the mid-point. The 'Republican' tag falls in the same quadrant as the Personal Experiences class, which suggests that a good number of Republican senators relied on this emotive class in their debates on the bill. That is, Republican senators tended to highlight the gruesome details of the abortion procedure by providing individual stories for an emotive punch. We noted earlier, however, that Boxer's tag for this class is highly significant and thus, as a Democrat, she appears anomalous in her attempt to counter the gruesome details of the procedure rhetoric with equally gruesome rhetoric detailing the turmoil of women who resorted to the procedure for their own health or to abort seriously deformed fetuses.

Secondly, the 'nay' and 'yea' tags at the top and bottom of the graph appear to reflect pole positions of the bill's opponents and proponents. Very near the nay tag is the Democrat tag, and both are in close proximity to the Constitutionality class. This suggests that opponents of the bill (of which most were Democrats) tended to focus on the issue of constitutionality, arguing that without a health exception the bill would violate the precedent of Roe v. Wade, while proponents framed their arguments around more emotive rhetoric (particularly the gruesome nature of the method as detailed in the Personal Experiences theme).

These observations suggest two broad lines of conflict in the debates over the bill. The first and primary (horizontal) conflict lends empirical support to the argument that the bill's supporters sought to divide D \& X from other abortion procedures by focusing on its more gory details. (In terms of a trade-off, this may be construed as more extreme versus less extreme forms of abortion.) We thus see Santorum, as sponsor, and other supporters (Ensign, Nickles and Enzi) clustered in the bottom left cell, near the Personal Experiences class. Indeed on 11 March, Enzi described the Republican strategy in framing the PBA ban. He maintained that the issue of the health exception was a side argument; the real motive of the bill was to force moderate pro-choice senators into taking a more extreme defensive posture by leaving them with no option but to endorse what was framed as an inhumane abortion procedure (italics added):

This is about life and death, and that is why the bill speaks specifically to life. What we tried to do in framing this argument was to come up with the most definite situation when those who are in favor of abortion are separated from those opposed to abortion. It is pretty much that simple. There will be some efforts to try to bring it back a little more to the middle so people can put a little bit of a spin on their decision, but that is what this is about. That is why a procedure was picked that is not taught any longer; a procedure was picked that the American Medical Association said is not needed anymore. That makes it pretty clear ... You can add all the qualifications you want to it, but if you cannot oppose partial-birth abortion, then you must be in favor of abortion.

The strategy could hardly be clearer: proponents 'picked' the D \& X procedure in order to frame abortion in starker, more unacceptable terms, thereby moving some pro-choice legislators to support the ban (and endorse the sentiments of Sen. Pat Moynihan, who years earlier had described the procedure as 'just too close to infanticide'). ${ }^{61}$ Other pro-choice senators (mostly women Democrats such as Boxer, Stabenow and Clinton) sought to recast

${ }^{61}$ Quoted in Saletan, Bearing Right, p. 234. 
and redirect the emotions surrounding the procedure to favour the patients. They countered the gruesome personal stories of their Republican colleagues with equally gruesome and emotive stories of women who experienced late term abortions under difficult and sad circumstances, although this left them on weaker ground in defending women who postponed the decision until late in the pregnancy, and little justification for the necessity of the D \& X procedure over the more standard D \& E procedure.

In short, this primary dimension can be interpreted as an attempt by the bill's supporters to frame the procedure as uniquely different from other abortion procedures (that is, morally unacceptable), and thereby leave moderate pro-choice senators with no middle ground upon which to stand. For Senators Boxer, Stabenow and Clinton, the only recourse was to counter the horror of infanticide with the horror of a deformed fetus and a distraught woman.

As will be further discussed in the next section, this primary dimension not only forced moderate pro-choice senators away from the middle ground, but was also important in shaping the final policy outcome in the Supreme Court. The framing of the D \& X procedure as infanticide was critical to the Court's decision to uphold the ban.

The second line of conflict is situated on the vertical axis, and it is this cleavage that appears to underpin the ultimate dimensionality of the roll-call vote (from Figure 1), as it pits the opponents of the bill (mostly Democrats) against its proponents (mostly Republicans). The content of this dimension appears to be the controversy surrounding the constitutionality of the omission of the health exception, with the Constitutionality theme extending to the very top of the spatial map, while all the three remaining classes are situated in the bottom quadrants. This, together with the close proximity of the Democrat and nay tags, suggests that while both opponents and proponents of the bill spoke to the theme of constitutionality, Democratic opponents of the bill dominated this discussion. (Unsurprisingly, there is also an overrepresentation of members of the Judiciary Committee - e.g., Feinstein, Durbin, Kennedy, Kyl, Grassley, Feingold and DeWine - who presumably felt compelled to speak to issues of constitutionality.)

The overall strategy of the pro-ban senators appears to have been one of forcing opponents of the ban to wage a battle on two fronts - (1) to defend a health exception which was said (by the pro-ban senators) to be medically unwarranted (and thereby not germane, given the congressional findings contained in the bill) and, in doing so, (2) to defend an abortion procedure which was framed by the pro-ban senators in a particularly gruesome way. Proponents of the bill thus sought to shift the abortion conflict away from the traditional issue of Choice, Rights \& Morality to two particular aspects of abortion on which pro-lifers perceived a more certain victory - recasting D \& X as infanticide and building a case against the health exception. By eliminating overt support for Roe v. Wade in the process (with the elimination of the Harkin amendment), proponents sought to further dissipate any middle ground in the abortion conflict, thereby intensifying the polarization on this issue within Congress.

\section{DISCUSSION AND CONCLUSION}

The case of the Partial-Birth Abortion Ban Act reveals that over three-quarters of the content of the Senate debates on this bill can be captured in a two-dimensional correspondence space. ${ }^{62}$ Surprisingly, the primary dimension in this discourse (which

${ }^{62}$ As noted earlier, a further factor accounts for another 22.7 per cent of the association, but this is not explored in this article. 
essentially pits an extreme abortion procedure against less extreme procedures) does not reflect the ultimate divide in the roll-call vote. Rather, the split between the yeas and nays is captured in the second dimension, as shown in Figure 3. A first dimension that does not reflect the final vote would appear, at first glance, to be an anomaly. Why did senators expend so much effort debating an aspect of the abortion ban that did not appear to form the core of their ultimate voting decision? Put another way, why did senators not spend more time debating the issue of the constitutionality of the health exception, if that indeed is what appears to have formed the basis of conflict in the final vote?

The answer rests with an understanding of the strategy of the proponents of the bill, which was to wage a two-pronged battle. Passage of the bill in Congress was never in serious doubt (given the Republican majority, previous successful votes on similar legislation and an assured signature of President Bush); rather, the larger battle was directed at the Supreme Court. By framing a specific type of abortion as morally unacceptable and by laying down the gauntlet to the Supreme Court, Santorum and other sponsors sought to further their incremental assault on abortion in general. Omitting both the exception for a woman's health and any endorsement of Roe v. Wade were clear signals of the bill's attempt to further polarize the abortion issue. The reason that the bill's supporters latched onto the D \& X procedure was that it enabled them to frame abortion in a particularly negative and passionate way, and thereby gain leverage in a larger anti-abortion struggle. Within the legislative arena, by framing the D \& X procedure as infanticide, proponents gained political points by forcing anti-ban senators into a difficult defensive position.

Yet if the strategy of the proponents was to wage battles on both emotive and constitutional fronts, we are still left with two basic dimensions of conflict. How did the constitutional front become the basis for the final vote? The simple answer is that the bulk of the opponents of the bill chose to devote more time to arguing the constitutional case than to defending a procedure that had been effectively framed in the bill as infanticide. This is not to say that opponents ignored the more difficult challenge of the infanticide frame: indeed, it seemed to have been left to a small number of women senators (who as Boxer reminded her audience, were empathetic mothers and grandmothers) to refute the framing of D \& X as inhumane. On average, however, opponents of the bill (mostly Democrats) shied away from the personal and emotive aspects in favour of legal and constitutional aspects. In short, while proponents of the bill defined the conflict in predominantly two dimensions, most of the bill's opponents opted to fight the (stronger and more objective) constitutional argument, thereby defining the content of the final vote.

In a more speculative vein, one might interpret the second dimension as the only relevant choice for the final vote, inasmuch as it provided the bill's opponents and proponents a clear choice - senators who voted nay argued that the missing health exemption was unconstitutional while the bill's proponents held this argument to be irrelevant. The primary dimension - the extreme nature of the abortion procedure - was a useful framing device for the pro-lifers (and indeed resonated clearly in Justice Kennedy's majority opinion in Gonzales v. Carhart). ${ }^{63}$ Yet both camps knew that lessening the extremity of the procedure was (and is) not the goal of the most ardent pro-lifers - the goal is to end all abortion procedures. Hence, opponents of the bill steered well clear of this argument and instead deliberately chose to vote on the constitutionality argument.

63 Justice Kennedy, Gonzales, Attorney General v. Carhart et al., certiorari to the United States Court of Appeals for the Eight Circuit, Argued 8 November 2006 - Decided 18 April 2007, No. 05-380. 
This case illustrates the tendency of strategic legislative actors to deploy various tools to gain victory - here, most conspicuously the rhetoric used to frame the D \& X procedure as infanticide. This helped to polarize positions on abortion even further by denying a middle ground on a particular abortion procedure. But more importantly, while we find two fundamental dimensions of verbal conflict in the Senate debates on the PBA Ban Act of 2003, it is senators' competing interpretations of the meaning of the constitution which seem to map best onto the determinative roll call. In sum, the analysis of voting behaviour may be important for some purposes, but it can sometimes miss the larger political reality. In this case, the reality was that the legislative process was not simply a channel for transforming general liberal-conservative attitudes into a social choice, but rather it served to reveal the primary dimension upon which senators legitimized their votes - namely, whether or not the ban could survive constitutional scrutiny.

\section{APPENDIX 1: DETAILS OF ALCESTE METHODOLOGY}

ALCESTE is textual analysis software that identifies a speaker's association of ideas and main arguments ideas and arguments which can then be correlated with the speaker's characteristics (party affiliation, constituency characteristics and so on). The package relies upon co-occurrence analysis, which is the statistical analysis of frequent word pairs in a text corpus. ALCESTE was developed by Max Reinert ${ }^{64}$ and has been applied in sociology and psychology ${ }^{65}$ and in political science. ${ }^{66}$ It has been described as a 'methodology' in so far as it 'integrates a multitude of highly sophisticated statistical methods', ${ }^{67}$ and: 'Taken together, the program realizes a complex descending hierarchical classification combining elements of different statistical methods like segmentation, hierarchical classification and dichotomization based on reciprocal averaging or correspondence analysis and the theory of dynamic clouds. ${ }^{68}$ More simply, it may be described as a marriage of textual and statistical analysis. ${ }^{69}$

${ }^{64}$ Max Reinert, 'Une methode de classification descendante hierarchique: application a l'analyse lexicale par contexte', Les Cahiers de l'Analyse des Données, 8 (1983), 187-98; Reinert, ALCESTE Users' Manual; Max Reinert, 'Le rôle de la répétition dans la représentation du sens et son approche statistique dans la méthode ALCESTE', Semiotica, 147 (2003), pp. 389-420.

${ }^{65}$ Martin Bauer, 'Classical Content Analysis: A Review', in Martin W. Bauer and George Gaskell, eds, Qualitative Researching with Text, Image and Sound: A Practical Handbook (London: Sage, 2000), pp. 131-51; Noel-Jorand et al., 'Discourse Analysis and Psychological Adaptation to High Altitude Hypoxia'; Noel-Jorand et al., 'A New Approach to Discourse Analysis in Psychiatry'; Noel-Jorand et al. 'Schizophrenia'; L. Lahlou, 'A Method to Extract Social Representations from Linguistic Corpora', Japanese Journal of Experimental Social Psychology, 36 (1996), 278-91; France Guerin-Pace, 'Textual Statistics. An Exploratory Tool for the Social Sciences', Population: An English Selection: New Methodological Approaches in the Social Sciences, 10 (1998), 73-95.

66 Mathieu Brugidou, 'Epitaphes, l'image de François Mitterrand à travers l'analyse d'une question ouverte posée à sa mort', Revue Française de Science Politique, 48 (1998), 97-120; Mathieu Brugidou, 'Argumentation and Values: An Analysis of Ordinary Political Competence Via An Open-Ended Question', International Journal of Public Opinion Research, 15 (2003), 413-30; Cheryl Schonhardt-Bailey, 'Measuring Ideas More Effectively: An Analysis of Bush and Kerry's National Security Speeches', PS: Political Science and Politics, 38 (2005), 701-11; Cheryl Schonhardt-Bailey, From the Corn Laws to Free Trade: Interests, Ideas and Institutions in Historical Perspective (Cambridge, Mass.: MIT Press, 2006).

${ }^{67}$ Nicole Kronberger and Wolfgang Wagner, 'Keywords in Context: Statistical Analysis of Text Features', in Bauer and Gaskell, eds, Qualitative Researching with Text, Image and Sound, p. 306.

${ }^{68}$ P. Bertier and J. M. Bouroche, Analyse des données multidimensionnelles (Paris: Presses Universitaires de France, 1975); C. Hayashi, 'On the Quantification of Qualitative Data from the Mathematics-Statistical Point of View', Annals of the Institute of Statistical Mathematics, 2 (1950); J. P. Benzecri, Pratique de l'analyse des données: linguistique et lexicologie (Paris: Dunod, 1981); Greenacre, Correspondence Analysis in Practice. Quotation from Kronberger and Wagner, 'Keywords in Context: Statistical Analysis of Text Features', p. 306.

${ }^{69}$ Roel Popping, correspondence with author, 29 October 2004. 
There are two preconditions for good results with ALCESTE: (1) the textual data must be consistent within the whole (for example, themes and conditions of production are both consistent); and (2) the text must be large enough for the statistical output to be relevant (with a minimum of 10,000 words). The software is particularly adept at analysing naturally occurring (or non-reactive) textual data. The Senate debates on the 2003 PBA ban fit these preconditions precisely: the speeches all relate to aspects of abortion, the total word count is 257,999 and the textual data are non-reactive.

ALCESTE determines word distribution patterns within a text, with the objective being to obtain a primary statistical classification of simple statements (or 'contextual units') ) $^{70}$ in order to reveal the most characteristic words, which in turn can be distinguished as word classes that represent different forms of discourse concerning the topic of the text. Through its dictionary, ALCESTE prepares the text by reducing different forms of the same word (in the form of plurals, suffixes, etc.) to the root form and transforms irregular verbs to the indicative, thereby producing a matrix of reduced forms. It also subdivides the corpus into 'function words' (articles, prepositions, conjunctions, pronouns and auxiliary verbs) and 'content words' (nouns, verbs, adjectives and adverbs). The content words are understood to carry the meaning of the discourse and the final analysis is based on these. (Content words are sometimes referred to as the 'meaningful words'.) The program creates a data matrix (an 'indicator matrix') which allows an analysis of statistical similarities and dissimilarities of words in order to identify repetitive language patterns. This matrix relates relevant words in columns and contextual units in rows, so that if a given word is present, a 1 is entered in the cell; otherwise, the entry is 0 . Then, using descending hierarchical classification analysis, the program identifies word classes. (The term 'class' is used for descending hierarchical classification analysis while the term 'cluster' is used for the more traditional ascending cluster analysis. ${ }^{71}$ The first class comprises the total set of contextual units in the initial indicator matrix. The program then attempts to partition that class into two further classes that contain different vocabulary and ideally do not contain any overlapping words. The methods used for this are optimal scaling and the adoption of a maximum $\chi^{2}$ criterion for cutting the ordered set of words. ALCESTE compares the distribution of words in each of the two new classes with the average distribution of words. Different forms of discourse that use different vocabulary will result in an observed word distribution that deviates systematically from one where the words are independent of each other. The procedure searches for maximally separate patterns of co-occurrence between the word classes. The $\chi^{2}$ criterion is thus used as a measure of the relationship that exists between words, rather than as a test.

Following an iterative process, the descending hierarchical classification method decomposes the classes until a predetermined number of iterations fails to result in further divisions. With each step, the descending hierarchical classification uses the first factor of the factorial analysis of correspondences; its top-down design thus allows it to eliminate class 'artefacts' ${ }^{72}$ The result is a hierarchy of classes, which may be schematized as a tree diagram.

The classification follows a specified procedure using $\chi^{2}$, and may be illustrated using Kronberger and Wagner's example of the decomposition of an original matrix into two classes (see Table 4). ${ }^{73}$

TABLE 4 Decomposition of a matrix

\begin{tabular}{|c|c|c|c|c|c|c|c|}
\hline & \multicolumn{2}{|c|}{$\begin{array}{c}\text { Specific vocabulary } \\
\text { of Class } 2\end{array}$} & \multicolumn{2}{|c|}{$\begin{array}{l}\text { Overlapping } \\
\text { vocabulary }\end{array}$} & \multicolumn{2}{|c|}{$\begin{array}{c}\text { Specific vocabulary } \\
\text { of Class } 3\end{array}$} & \\
\hline & food & fruit & say & word $j$ & cure & cancer & \\
\hline Class 2 & 45 & 12 & 20 & $k_{2 j}$ & 0 & 0 & $k_{2}$ \\
\hline \multirow[t]{2}{*}{ Class 3} & 0 & 0 & 21 & $k_{3 j}$ & 33 & 20 & $k_{3}$ \\
\hline & 45 & 12 & 41 & $k_{j}$ & 33 & 20 & $k$ \\
\hline
\end{tabular}

70 For ALCESTE, 'statements' are defined as 'contextual units'. The program automatically determines contextual units with reference to punctuation and the length of the statement up to a maximum of 250 characters.

${ }^{71}$ Kronberger and Wagner, 'Keywords in Context', p. 308.

72 Max Reinert, correspondence with author, 24 October 2006.

73 Kronberger and Wagner, 'Keywords in Context', p. 309. 
Classes 2 and 3 are optimally separate in that they have as little overlap in words as possible.

The numbers in the table $\left(k_{2 j}, k_{3 j}\right)$ indicate the frequency of contextual units for each class containing a specific word $j$. In our example, class 2 consists of statements containing words like 'food' and 'fruit', while words like 'cancer' and 'cure' are typical for class 3 . Of course, it will rarely be possible to separate statements such that words occurring in one class do not appear in the other. There will always be some overlapping vocabulary, like the word 'say' in the example. ${ }^{74}$

The $\chi^{2}$ procedure then establishes 'out of all possible procedures' two classes that maximize the following criterion:

$$
\begin{aligned}
& \chi^{2}=k_{2} k_{3} \sum_{j \in J}\left[\left(\frac{k_{2 j}}{k_{2}}-\frac{k_{3 j}}{k_{3}}\right)^{2} \div k_{j}\right], \text { where } \\
& k_{2 j}=\sum_{i \in I_{2}} k_{i j} ; k_{2}=\sum_{i \in I_{1}} k_{2 j} ; k_{j}=k_{2 j}+k_{3 j} .
\end{aligned}
$$

APPENDIX 2: CORRESPONDENCE ANALYSIS OF CLASSES FOR SENATE DEBATES, REPRESENTATIVE WORDS

Figure 4, overleaf, provides a more detailed correspondence graph of the representative words in the analysis. This graph allows us to visualize the spread and overlap of the representative words from the analysis. The white dots represent the centre point for each graph (as depicted in Figure 3), while the shaded areas help to illustrate the dispersion of each class.

74 Kronberger and Wagner, 'Keywords in Context'. 


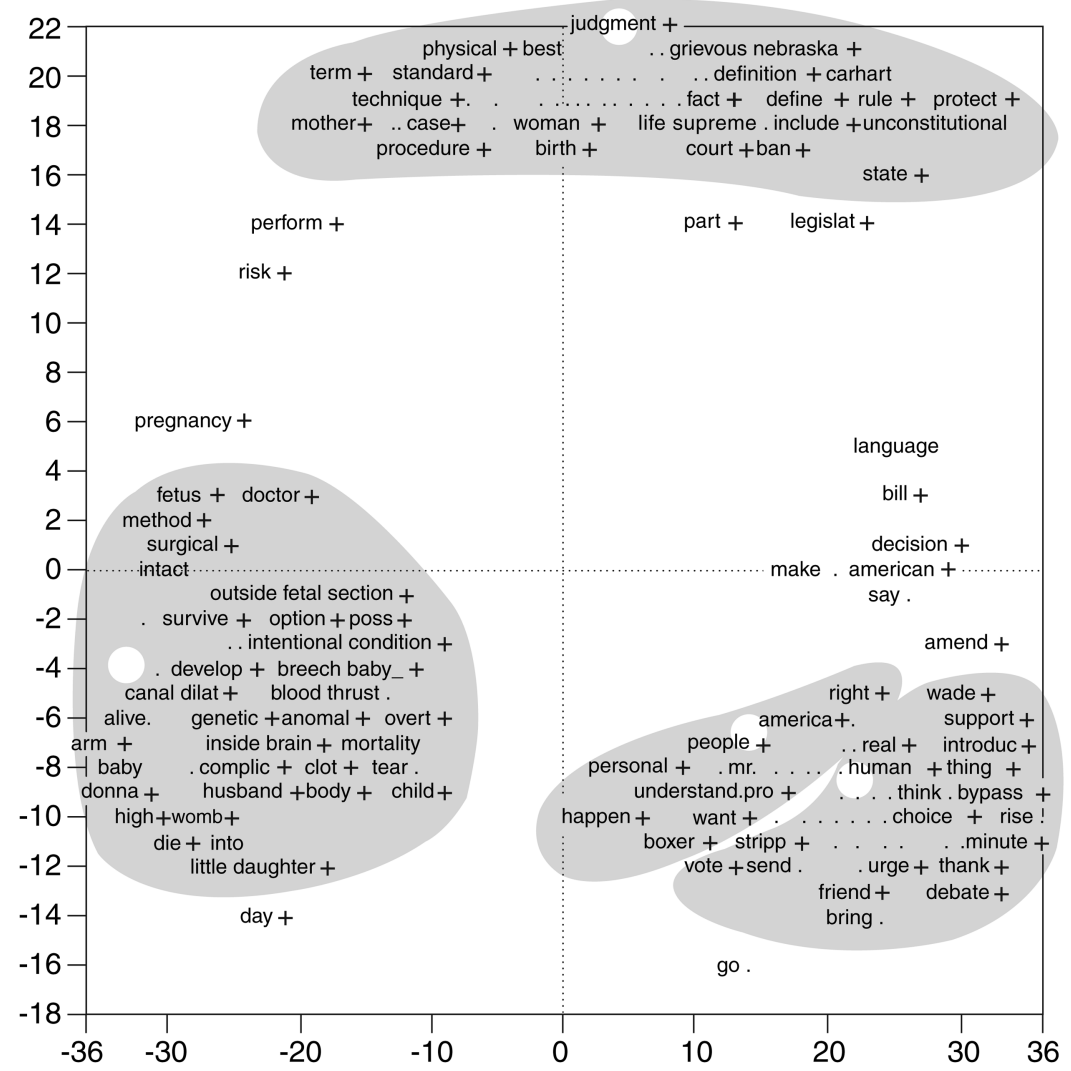

Additional Data Points

\begin{tabular}{|c|c|c|c|c|c|c|c|c|c|}
\hline$x$ & $y$ & $x$ & $y$ & $x$ & $y$ & $x$ & $y$ & $x$ & $y$ \\
\hline 4 & 20 post+ & -32 & -5 hysterotom+ & -32 & -6 sharp+ & 3 & 20 license+ & 15 & -8 country \\
\hline 1 & 20 statute + & -32 & -5 induce+ & -33 & -4 size & 5 & 20 appropriate+ & 17 & -8 motion+ \\
\hline 3 & 20 stenberg & -32 & -5 induction+ & -32 & -6 skull+ & 7 & 20 interest+ & 18 & -8 commend \\
\hline 4 & 20 undue & -32 & -6 infection+ & -32 & -7 stroke+ & 8 & 20 except+ & 19 & -8 side+ \\
\hline 3 & 20 vague+ & -32 & -5 infertility & -33 & -4 suck+ & -7 & 19 require+ & 20 & -8 cosponsort \\
\hline 3 & 20 viability & -32 & -6 insert+ & -32 & -5 suction+ & -5 & 19 medicine+ & 22 & -8 president+ \\
\hline 2 & 20 viable+ & -32 & -6 instrument+ & -32 & -5 survival & -3 & 19 prohibit+ & 19 & -9 committee+ \\
\hline 4 & 20 violate+ & -32 & -7 joy & -32 & -5 tube & -2 & 19 medical+ & 20 & -9 confer + \\
\hline-32 & -6 cervix & -32 & -5 katherine+ & -32 & -6 ultrasound + & 1 & 19 consult+ & 21 & -9 house+ \\
\hline-32 & -5 cesarean & -32 & -5 kidney+ & -32 & -5 uterine & 2 & 19 health+ & 22 & -9 leader+ \\
\hline-32 & -5 collapse+ & -32 & -5 labor & -32 & -7 utero & 3 & 19 necessary & 23 & -9 consent \\
\hline-32 & -5 cord & -32 & -5 leg+ & -32 & -6 uterus & 4 & 19 evidence+ & 17 & -10 commit+ \\
\hline-32 & -5 counselor+ & -32 & -5 liver & -32 & -5 vaginal+ & 5 & 19 associ+ & 19 & -10 harkin+ \\
\hline-32 & -6 damage+ & -32 & -5 living & -33 & -5 watts + & 8 & 19 restrict+ & 20 & -10 final + \\
\hline-32 & -5 dead+ & -32 & -7 pain+ & 19 & -9 madam & -13 & 18 physician+ & 21 & -10 pass + \\
\hline-32 & -5 deliver+ & -32 & -5 pair & 18 & -9 nickles+ & -7 & 18 specific+ & 22 & -10 floor \\
\hline-32 & -5 dilate & -32 & -6 paralysis+ & 18 & -9 remainder & 14 & 18 clear+ & 23 & -10 senate+ \\
\hline-32 & -5 embolism+ & -32 & -6 partially & 21 & -10 sign + & -33 & -2 extraction+ & 24 & -10 colleague + \\
\hline-32 & -5 evacuation & -32 & -5 perfor+ & 19 & -10 yield + & -32 & -3 outcome+ & 20 & -11 bipartisan \\
\hline-32 & -6 feet & -33 & -5 perinatologi & 4 & 21 findings & -31 & -3 week+ & 22 & -11 disagree+ \\
\hline-32 & -5 finger+ & -32 & -5 placenta & 5 & 21 broad+ & -31 & -4 cervical & 24 & -11 republic+ \\
\hline-32 & -5 fluid + & -32 & -5 previa+ & -3 & 20 patient+ & -31 & -6 blind + & 25 & -11 pennsylvania \\
\hline-33 & -5 gestat+ & -32 & -6 pull+ & -2 & 20 apply & 22 & -6 reaffirm+ & 28 & -11 senator+ \\
\hline-33 & -5 hand+ & -32 & -5 quick+ & -1 & 20 injury+ & 20 & -7 judiciary & 29 & -11 issue+ \\
\hline-32 & -6 head+ & -32 & -7 rate+ & 0 & 20 alternative+ & 21 & -7 resolution+ & 22 & -12 sense+ \\
\hline-32 & -5 hemorrhage+ & -32 & -6 rupture+ & 1 & 20 abortion+ & -29 & -8 normal+ & & \\
\hline-32 & -5 hysterectom+ & -32 & -6 scissor+ & 2 & 20 circumstance & 12 & -8 society+ & & \\
\hline
\end{tabular}

Fig. 4. Senate debates on Partial-Birth Abortion Ban Act - word distribution in correspondence space 